Review

\title{
Forest and Wellbeing: Bridging Medical and Forest Research for Effective Forest-Based Initiatives
}

\author{
Ilaria Doimo*(D), Mauro Masiero $\mathbb{D}$ and Paola Gatto $\mathbb{D}$ \\ Department of Land, Environment, Agriculture and Forestry, Università degli Studi di Padova, \\ viale dell’Università 16, 35020 Legnaro, Padova, Italy; mauro.masiero@unipd.it (M.M.); \\ paola.gatto@unipd.it (P.G.) \\ * Correspondence: ilariadoimo@gmail.com
}

Received: 17 June 2020; Accepted: 19 July 2020; Published: 22 July 2020

\begin{abstract}
Research Highlights: This review gives an overview of existing literature on the emerging topic of human wellbeing-forest contact nexus and provides a preliminary framework linking forests to wellbeing by highlighting key variables affecting this relationship. Background and Objectives: Existing literature reveals the psychological, physiological and social wellbeing benefits of contact with forest ecosystems; however, the role of forests in this relationship remains largely unexplored. The objectives of this review are twofold: (i) to provide an overview of the contributions of forest experiences to human wellbeing and the related interplay with forest ecosystems and (ii) to identify knowledge gaps to inform future research and systematize information available for forest managers and planners to support the development of effective forest-based initiatives. Materials and Methods: A scoping review was performed with a five-phase method integrating a systematic approach on Scopus, Web of Science and PubMed databases and snowball search. Studies were analyzed using a descriptive-analytical method. Results: Overall, 93 papers were included in the review. These are mainly from health-related sciences providing limited information for forest managers, planners and practitioners. Four main underlying variables of the forest-wellbeing relationship are identified: interaction, forest features, sensorial dimension of the forest and individual traits and reactions. Conclusions: Forest-based initiatives provide good opportunities for supporting public health and time spent in contact with forests seems to have a "health-bonus". Whether and to what extent forest management can contribute to this is still poorly investigated. There is the need to better study causal relationships between specific forest features, type of interactions, frequency and "dose" of experiences, individual reactions and needs and wellbeing effects to maximize benefits from forest-based initiatives.
\end{abstract}

Keywords: forest-based initiatives; forest bathing; forest therapy; wellbeing; Shinrin-Yoku; forest management

\section{Introduction}

Increasing urbanization, sedentary lifestyles, virtualization of social relationships, insecure employment, climate change and unprecedented conditions like the Covid-19 lockdown led to an escalation of stress and anxiety in the global population [1-3]. Stress is one of the leading causes of noncommunicable diseases (NCD) such as cardiovascular, metabolic, immunological, oncological and psychiatric disorders [4-6]. Both in Europe and worldwide, NCD are increasing their incidence and mortality [4], hence measures for stress recovery and promotion of healthy lifestyles have become crucial for public health. 
Over the past decade, research focused increasing attention on the preventive and beneficial effects of being in contact with natural ecosystems [7-16]. Among this body of research, an experience in forest is considered one method to positively influence mental, physical and social wellbeing $[17,18]$. Indeed, there is increasing evidence suggesting that forests, including both natural and urban woodlands, offer effective opportunities for enhancing people's quality of life $[19,20]$, reducing public health care costs [21-23] and potentially providing alternative and innovative income sources for the forest sector. Accordingly, the number and variety of forest-based initiatives for health and wellbeing have increased [24] worldwide: from Shinrin-Yoku and forest bathing (FB) in Japan to healing forests in Korea, from social forestry to art exhibitions, from burial forests to forest kindergartens, examples are thriving $[25,26]$.

Accordingly, medical research on the specific role of contact with nature in decreasing stress levels has grown. Several authors have suggested that natural environments, including forests, promote wellbeing by restoring mental resources and relaxation more than built environments [27-30]. Research has increasingly focused on nature as a cost-effective solution for addressing NCD [6,7]: according to the Nature and Forest Therapy approach [31,32], compared with a city setting, contact with a forest is more efficient for experiencing an immediate sense of mental and physical relaxation [23,33]. Evidence-based medicine has demonstrated the intuitive knowledge that spending time in easily accessible and pleasant forests is good for physiological [34,35] and psychological relaxation [36-38] as well as for social wellbeing, because it increases relational skills and self-esteem, supports spiritual and cultural values and enhances positive attitudes towards the environment in general [39-41].

However, while forest-wellbeing relationships have been widely investigated from the medical perspective, they are still largely unexplored from the forest-science perspective and there seems to be inadequate support for interdisciplinary approaches and cooperation between forestry and public health [42-44]. To be effective there is the need of an understanding of the environmental features that support or promote restoration and wellbeing for different groups of people [29,45]. Few efforts to investigate the links between health effects and different natural settings and management choices $[13,46,47]$ or to address public health issues with forest management $[24,42,43,48]$ have so far been undertaken. Existing reviews on the health effects of forest exposure are sectorial and provide a partial perspective: some are aimed at assessing the quality of the studies, and often reveal poor methodological approaches [23,49]; others [26,37,38,50] explore single health aspects based on a restricted number of papers or are connected to specific experiences [51]; some studies focus on specific geographical areas [17,52] or initiatives [22]. In general, the literature misses a focus on forest ecosystem characteristics, as also reported by a recent systematic review revealing lack of description and information about the forest ecosystems involved in the studies [53].

To fill this gap, this paper has thoroughly reviewed the existing medical literature on effects of forest-based initiatives for wellbeing and explored the interplay between forest features-such as forest management, time spent in the forest, different sensorial dimensions of the forest-and individual traits, preferences and pre-existence of specific health conditions and health effects. An analytical framework systematizing the information and bridging medical and forest management perspectives is proposed. This review is meant to be useful for forest managers, researchers, practitioners and planners who wish to design effective forest-based initiatives for promoting people's mental, physical and social wellbeing.

The paper is organised in five sections. After the first introductory section, the second describes the review methodological approach; the third section presents and discusses the results, with a focus on studies' characteristics, design and procedures, and their results in terms of effects on health and wellbeing. In the fourth section, research gaps and their implications for policy-making and future research needs are highlighted. Conclusions and key-findings are presented in the fifth section. 


\section{Materials and Methods}

The review considers multiple types of activities taking place in forest ecosystems-i.e., walks, exposure, forest therapy (FT), FB and indoor tests-that have multiple effects on health and wellbeing. To fulfil its objectives, a scoping review was preferred to a systematic one as the method best suited to approach a growing body of literature with an original point of view. Similar to systematic reviews, scoping reviews rely on rigorous and transparent methods but differ in purpose and approach; while systematic reviews assess the quality of evidence in a specific field, scoping reviews contain inductive elements and are hence more helpful to clarify conceptual boundaries and identify research gaps [54-56].

The methodology follows the 5-phase model proposed by Arksey and O'Malley [56,57] and integrates the Preferred Reporting Items for Systematic Reviews and Meta-Analyses (PRISMA) approach to the screening and selection (phase 2 and 3) of relevant papers (Figure 1).

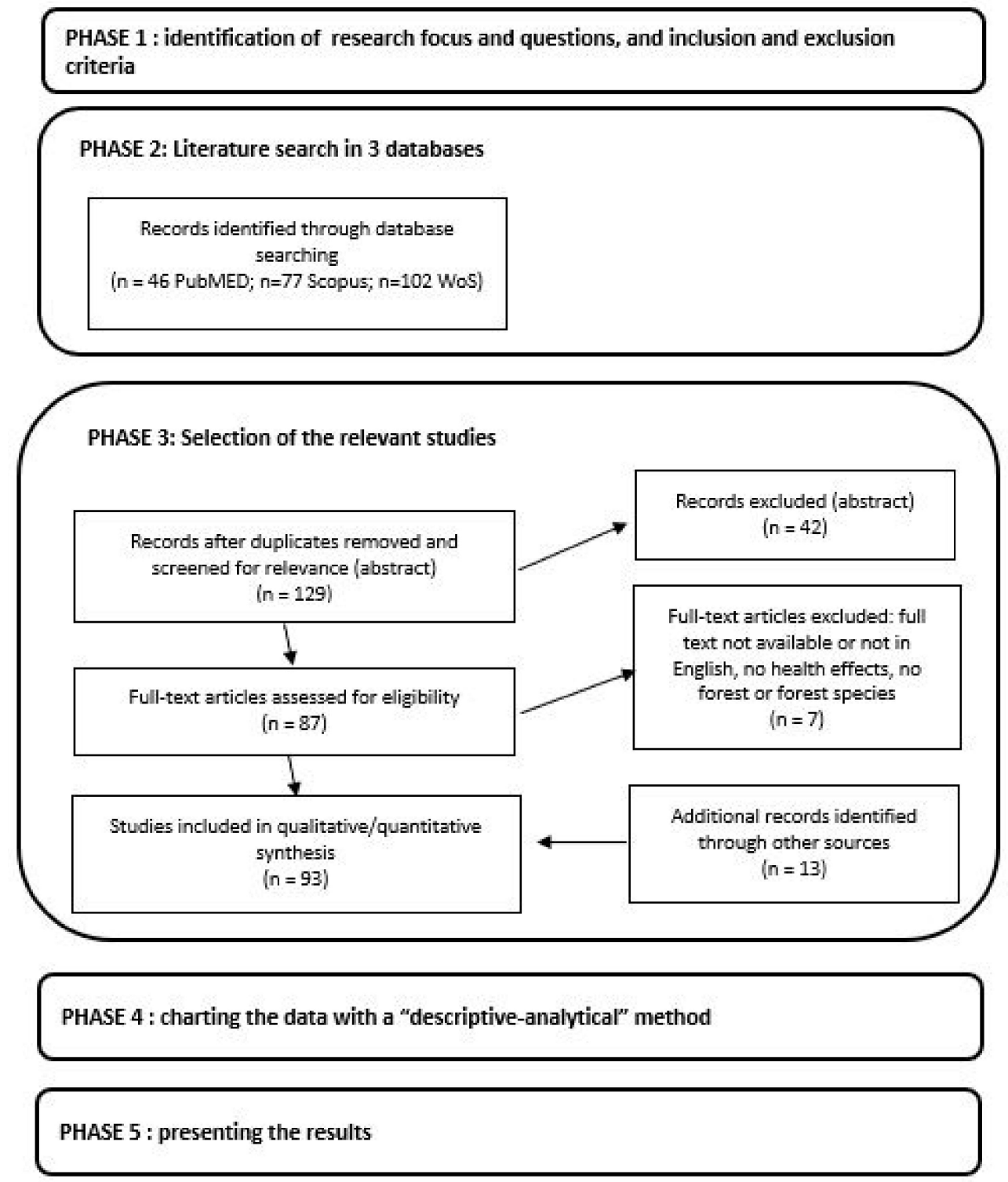

Figure 1. Flow diagram illustrating the 5 phases of the review incorporating Preferred Reporting Items for Systematic Reviews and Meta-Analyses (PRISMA) methodology. 
The five methodological phases are as follows:

1. Identify focus, research questions, inclusion and exclusion criteria, suitable keywords for the literature search. The review focuses on empirical studies on the effects of forest-based experiences on human wellbeing. To this end, the words "wellbeing" and "health" are used interchangeably and — consistently with the World Health Organization's (WHO) approach [58]—refer to the fulfilment of the three wellbeing constituents, i.e., physical, mental and social wellbeing. Inclusion criteria for research to be considered in the review were (1) papers only (not book chapters); (2) papers published in English, (3) from 1990 to 2019. Studies based on laboratory tests, using video and audio materials and byproducts clearly taken from a forest ecosystem and/or from forest tree species, were both considered, since they enable the effects of single sensorial stimuli of the forest experience to be isolated. All types of interaction with the forest ecosystem, from a simple walk to organized therapy programmes were covered, as well as different forest typologies and settings. Exclusion criteria were (a) papers with only abstract available; (b) tests performed on animals and not on humans; (c) tests performed in gardens, with ornamental plants and flowers, non forest tree species, single trees in gardens, street trees, plants indoors, and where there is not enough information on the host ecosystem enabling a clear recognition; (d) environmental hazards such as air pollution or noise, and their pathogenic impacts; (e) review papers. No limitations were set in geographical terms. The review chose not to focus on the study design of the experiments conducted; therefore, no exclusion criteria were set on this specific aspect. Since no umbrella term is widely used, "forest therapy", "forest bathing" and Shinrin-Yoku were identified as the main terms used in the literature $[17,22]$ and suitable keywords for a preliminary search. The final set of selected keywords and operators enabling to maintain a wide scope while intercepting the relevant literature on the topic was: (forest ${ }^{*}$ ) AND ("forest therap" " OR "shinrin-yoku" OR "forest bath " OR "forest exposure") AND ("health" OR "wellbeing" OR "health effects" OR "social" OR "psychological" OR "physiological").

2. Identify relevant papers. The identified keywords were used to perform a search via three databases: Scopus, Web of Science and PubMed. The search was replicated for each database and the keywords were identified in the paper title, abstract and keywords (topic for Web of Science databases). Snowball references were also added.

3. Select relevant studies by applying inclusion and exclusion criteria for eligibility by accessing and reading each identified paper in full.

4. Chart the data with a "descriptive-analytical" method. In order to provide a synthesis and original interpretation of the data, information from the identified papers was extracted through the application of coding criteria using a standardized coding matrix in Excel (Microsoft Corporation, Seattle, WA, USA) given in Table S1 and Figure 2. The coding criteria were identified with an iterative approach informed by the studies included and relevant Shinrin-Yoku literature, in response to the research question and specific review objectives. The following quantitative and qualitative data were extracted from each study:

a. description of the case study methodology. The elements extracted for describing the case study were year of publication, country of the study, discipline of the journal, number of participants in the experiment, participant's characteristics, timing of the study, study design (settings) and methodology (quantitative/qualitative).

b. effects on wellbeing: the classification of the effects on wellbeing was mainly inspired by public health sciences $[10,22,23,52]$ and simplified with the aim of making the topic more accessible and an entry point for in-depth follow-ups. Three categories of effects were considered: 
- $\quad$ psychological effects, which are usually measured with subjective self-reported tests; they were further divided into (i) affection, depression, mood and anxiety [28]; (ii) cognitive, such as attention restoration and mental relaxation effects; and (iii) effects on vigour and vitality [10,59].

- $\quad$ physiological effects, which are usually assessed through proxy parameters revealing changes in physiological stress conditions. Such effects were subdivided according to the different physiological systems: immune, nervous, cardiocirculatory, respiratory and general health effects. Specific effects on the endocrine system, i.e., decreased levels of cortisol, adrenaline and noradrenaline, were considered under the nervous system (This is a simplification, supported by the fact that in the literature, endocrine activity is often measured as a proxy to understand the response of the autonomic nervous system to forest exposure).

- social wellbeing effects, which involve the interaction with other people and the building of "self" in relation to society and community. To address them, we referred to and adapted evidence from nature contact studies [60-62] and categories of forest cultural ecosystem services provided by the ecosystem service literature [63-66]: stimulation of social skills, emotional skills, improvement of self-esteem, cultural and/or spiritual inspiration, support of positive behaviours towards health and environment.

c. features of the forest ecosystem and environment such as assessments on different management practices (including information on tree species), or different forest settings and the related specific effects on wellbeing. Although not being a forest ecosystem feature per se, season was also included within this category as it may have a significant direct influence on forest features.

d. typologies of interactions with the forest ecosystem: these were divided into direct (i.e., on-site) and indirect interactions. Direct or on-site interactions include simple activities such as walking, watching or being exposed to the forest and more complex activities such as FB or Shinrin-Yoku and FT. Although there is not a fully clear and univocal definition for the last two activities, FB is here understood as consisting of organized health promotion activities offering a combination of walking and relaxation activities in the forest, accompanied by a guide and often limited to a single session. FT refers instead to guided itineraries including different stations and structured activities, such as aromatherapy, meditation, yoga, Qi-Gong, craftwork sessions and other workshops, often organized as longer-term programmes including several sessions in the forest and targeted at selected groups of people as well as delivered in close collaboration with practitioners from the medical sector. Indirect or offsite interactions include offsite experiences like synthetic or virtual stimulations through 3-D forest images or olfactive stimulations.

e. sensory dimensions engaged by the forest experience: they were divided into vision, olfaction, sense of touch, hearing and taste. The sense of vision is in turn divided in "simple visual" stimuli, when sight differs from seeing a natural landscape (e.g., forest) rather than an urban one, yet no attention is paid to determining the specific effects. "Detailed visual" stimuli occur when the sense of sight is isolated (e.g., video stimulation) or when additional details enable the direct link between sight and wellbeing effects to be stressed (e.g., seeing different forest settings, seeing or not seeing a forest).

5. Present the results of the literature analysis. Initially, an overview of the studies is provided by aggregating the studies according to the above-mentioned categories and summarizing them in a narrative. Then, the underlying variables influencing the effects of the experiences on human wellbeing are identified and systematized in the discussion, resulting in an analytical framework and a pathway from forest to health. 


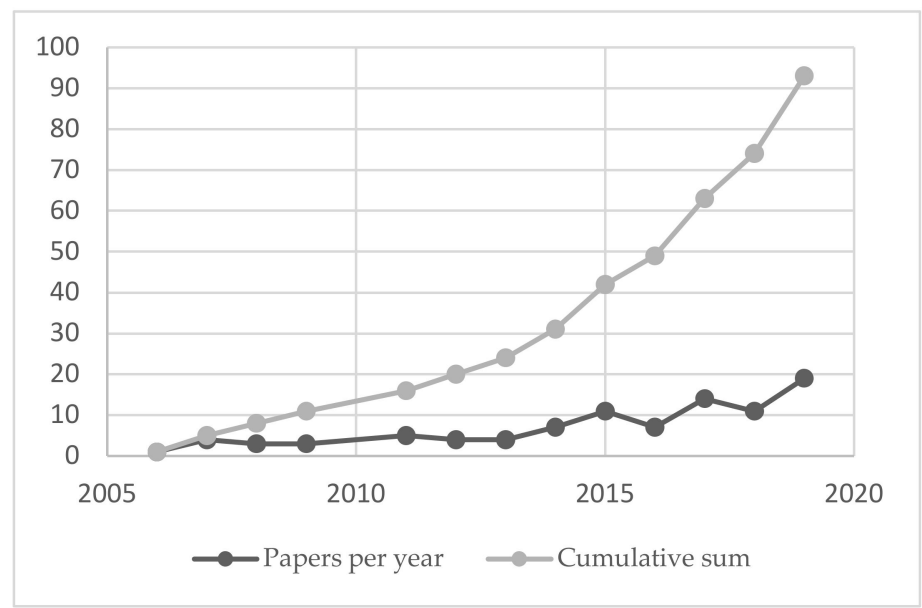

Figure 2. Number of papers published per year and their respective cumulative trend.

\section{Results and Discussion}

In the next sections the overall findings of the literature analysis are presented first (Section 3.1) and then discussed with a focus on the health effects deriving from forest contact (Section 3.2). Available information on the variables influencing the forest-wellbeing relationship are identified (Sections 3.3-3.6) and finally systematized (Section 3.7).

\subsection{Overview of the Included Studies}

The literature search completed in December 2019 identified 129 potentially relevant articles, of which 49 did not meet the eligibility criteria. Snowball searches included 13 additional studies, for a total of 93 relevant papers. A summary of results of the literature analysis according to the coding criteria is shown in Table 1 and discussed in the corresponding sections, while the complete dataset is presented in Table S1. The number of papers published has grown from one in 2006 to fifteen papers in 2019 (Figure 2), with 65\% of the studies published from 2015 to 2019. The majority (87\%) of studies were performed in Asian countries where Japan holds the primate with 49 studies. The rest of the studies were conducted in European countries: Poland $(n=5)$, Sweden and Great Britain $(n=2)$, Denmark, Finland and Spain $(n=1)$. Most studies $(n=62)$ were published in medicine-related journals, followed by forestry-related journals $(n=24)$; the rest were found in Geographical Science, Landscape and Urban Planning and Tourism related journals (Table S1).

Studies' sample size shows a great variability in the number of subjects involved, but most of them include between 12 and 30 subjects (35.9\%), with the maximum sample size in a single study of 5109 [67] and the minimum of 6 subjects [68]. The study population of the studies range from healthy people ( $n=71$ studies) to subjects with pre-existing mental disorders or chronic diseases $(n=18$ studies). Studies investigating people with pre-existing health conditions, disorders and diseases focus on hypertension, sleeping disorder, chronic pain, pulmonary chronic obstructive disease, stress and post-traumatic disorder. Further details on these categories are reported in Section 3.6. Effects of direct and indirect contact with the forest ecosystems are measured with quantitative approaches in 84 papers, with qualitative approaches in 4 papers and with a mixed approach in one paper only.

Looking at study procedures, $61.3 \%$ of the studies are conducted as single contact (i.e., both direct and indirect, lasting less than one day) with the forest ecosystem. These single contacts lasted less than $15 \mathrm{~min}$ in $26 \%$ of the cases. In the remaining $34.4 \%$ of the papers reviewed, the studies are conducted as repeated visits to the forest ecosystem. The study with the shortest intervention provided $60 \mathrm{~s}$ of indoor stimulation [69] and $10 \mathrm{~min}$ of direct forest exposure [70]. The longest intervention monitored lasted 11 weeks, $4 \mathrm{~h}$ per week [68] and another one was conducted over a period of 3 months for a total of 22 visits [39]. Numerous studies report unclear timing. Most studies (45\% of those reviewed) assess the changes in human wellbeing before and after being in contact with a forest ecosystem rather than 
an urban environment. Direct contact is the most used type of interaction to assess the wellbeing effects $(86 \%)$, while the remaining $14 \%$ investigate the effects of indirect contact with forest elements mediated by sensorial stimuli conducted in laboratory settings. Considering that 8 of the reviewed studies used a combination of two different interactions, simple activities such as walking or observing the forest are the most used to assess changes in wellbeing (57.7\%), while activities that require a higher level of organization such as FB and FT are used in $29.7 \%$ of the studies reviewed and indoor stimulation are used in $12.8 \%$. Additional information on the specific sensorial elements of the forest responsible for wellbeing effects are given by $32.3 \%$ of the papers.

Concerning the effects on human wellbeing, provided that almost all papers measure more than one health parameter, the most mentioned effects are psychological ones, reported by $82 \%$ of the papers, while physiological effects are reported by $77.4 \%$ and social effects by $10.7 \%$ of the studies. Figure 3 shows which are the most investigated subcategories of effects with statistically significant results (with level of significance established within each paper).

Table 1. Summary of results of the literature analysis.

\begin{tabular}{|c|c|c|}
\hline Coding Criteria & Categories & Results (N-\%) \\
\hline \multirow{3}{*}{ Publication Year } & Before 2010 & $11-12 \%$ \\
\hline & $2011-2015$ & $31-33 \%$ \\
\hline & 2016-2019 & $51-55 \%$ \\
\hline \multirow{6}{*}{ Country } & Japan & $49-53 \%$ \\
\hline & Korea & $15-16 \%$ \\
\hline & China & $14-15 \%$ \\
\hline & Poland & $5-5.3 \%$ \\
\hline & Taiwan & $3-3.2 \%$ \\
\hline & Others & $7-7.5 \%$ \\
\hline \multirow{3}{*}{ Journal's discipline } & Forestry related & $66-26 \%$ \\
\hline & Medicine related & $24-71 \%$ \\
\hline & Others & $3-3 \%$ \\
\hline \multirow{2}{*}{ Characteristics of participants } & Healthy & $74-80 \%$ \\
\hline & $\begin{array}{l}\text { Nonhealthy with pre-existing } \\
\text { conditions/diseases }\end{array}$ & $19-20 \%$ \\
\hline \multirow{5}{*}{ Number of participants $X$} & $X \leq 12$ & $17-18 \%$ \\
\hline & $13-30$ & $32-34 \%$ \\
\hline & $31-100$ & $31-33 \%$ \\
\hline & $X>100$ & $12-13 \%$ \\
\hline & NA & $1-1 \%$ \\
\hline \multirow{7}{*}{ Timing } & Up to $15 \mathrm{~min}$ & $26-28 \%$ \\
\hline & $16-30 \mathrm{~min}$ & $10-11 \%$ \\
\hline & $31 \mathrm{~min}-1 \mathrm{~h}$ & $8-8.6 \%$ \\
\hline & $2 \mathrm{~h}-1$ day & $13-13.9 \%$ \\
\hline & $2-3$ days & $16-17.2 \%$ \\
\hline & More than 3 days & $16-17.2 \%$ \\
\hline & NA & $4-4.3 \%$ \\
\hline
\end{tabular}


Table 1. Cont.

\begin{tabular}{|c|c|c|}
\hline Coding Criteria & Categories & Results (N-\%) \\
\hline \multirow{6}{*}{ Study Design (settings) } & Forest vs. City (alone) & $42-45 \%$ \\
\hline & Forest vs. Other settings/activities & $13-14 \%$ \\
\hline & Different forests settings/stimuli & $14-15 \%$ \\
\hline & Same forest & $20-22 \%$ \\
\hline & Indoor/artificial stimuli & $3-3 \%$ \\
\hline & Others & $1-1 \%$ \\
\hline \multirow{2}{*}{ Type of Interaction-Direct Simple } & Walking or physical activity & $36-35.6 \%$ \\
\hline & Passive observation/exposure & $22-21.7 \%$ \\
\hline \multirow{2}{*}{ Type of Interaction-Direct Organized } & Forest Bathing & $7-6.9 \%$ \\
\hline & Forest Therapy & $23-22.7 \%$ \\
\hline Type of Interaction-Indirect & Indoor or artificial stimulation & $13-12.8 \%$ \\
\hline \multirow{7}{*}{ Sensorial Elements } & Visual with details & $22-23.6 \%$ \\
\hline & Olfactive & $2-2.1 \%$ \\
\hline & Auditive & $2-2.1 \%$ \\
\hline & Tactile & $1-1 \%$ \\
\hline & Taste & $1-1 \%$ \\
\hline & Combined-visual and olfactive & $2-2.1 \%$ \\
\hline & NA & $63-67.7 \%$ \\
\hline \multirow{2}{*}{ Method } & Quantitative & $88-94.6 \%$ \\
\hline & Qualitative & $5-5.4 \%$ \\
\hline \multirow{3}{*}{ Effects on Psychological Wellbeing } & Depression, anxiety and mood & $61-67.7 \%$ \\
\hline & Mental relaxation-Attention restoration & $50-60 \%$ \\
\hline & $\begin{array}{l}\text { Vitalizing effects, sense of wellbeing, } \\
\text { subjective pain }\end{array}$ & $52-61 \%$ \\
\hline \multirow{5}{*}{ Effects on Physiological Wellbeing } & $\begin{array}{l}\text { Immune system (e.g., Natural Killer Cells } \\
\text { (NKcells), insulin, oxidative stress) }\end{array}$ & $16-17.2 \%$ \\
\hline & $\begin{array}{l}\text { Nervous system (e.g., heart rate, salivary } \\
\text { cortisol, oxyhemoglobin) }\end{array}$ & $44-58 \%$ \\
\hline & Cardiocirculatory system & $28-37.6 \%$ \\
\hline & Respiratory System & $2-3.2 \%$ \\
\hline & $\begin{array}{c}\text { Health promotion in general } \\
\text { (e.g., Health-Promoting Lifestyle Profile } \\
\text { (HPLP)-II, metabolism, sleep, more active life) }\end{array}$ & $7-7.5 \%$ \\
\hline \multirow{5}{*}{ Effects on Social Wellbeing } & Social skills & $3-3.2 \%$ \\
\hline & Emotional skills & $2-2 \%$ \\
\hline & Self-esteem & $7-7.5 \%$ \\
\hline & Inspiration (spiritual and artistic) & $1-1 \%$ \\
\hline & $\begin{array}{l}\text { Positive behaviour towards } \\
\text { environment/health }\end{array}$ & $3-3.2 \%$ \\
\hline
\end{tabular}




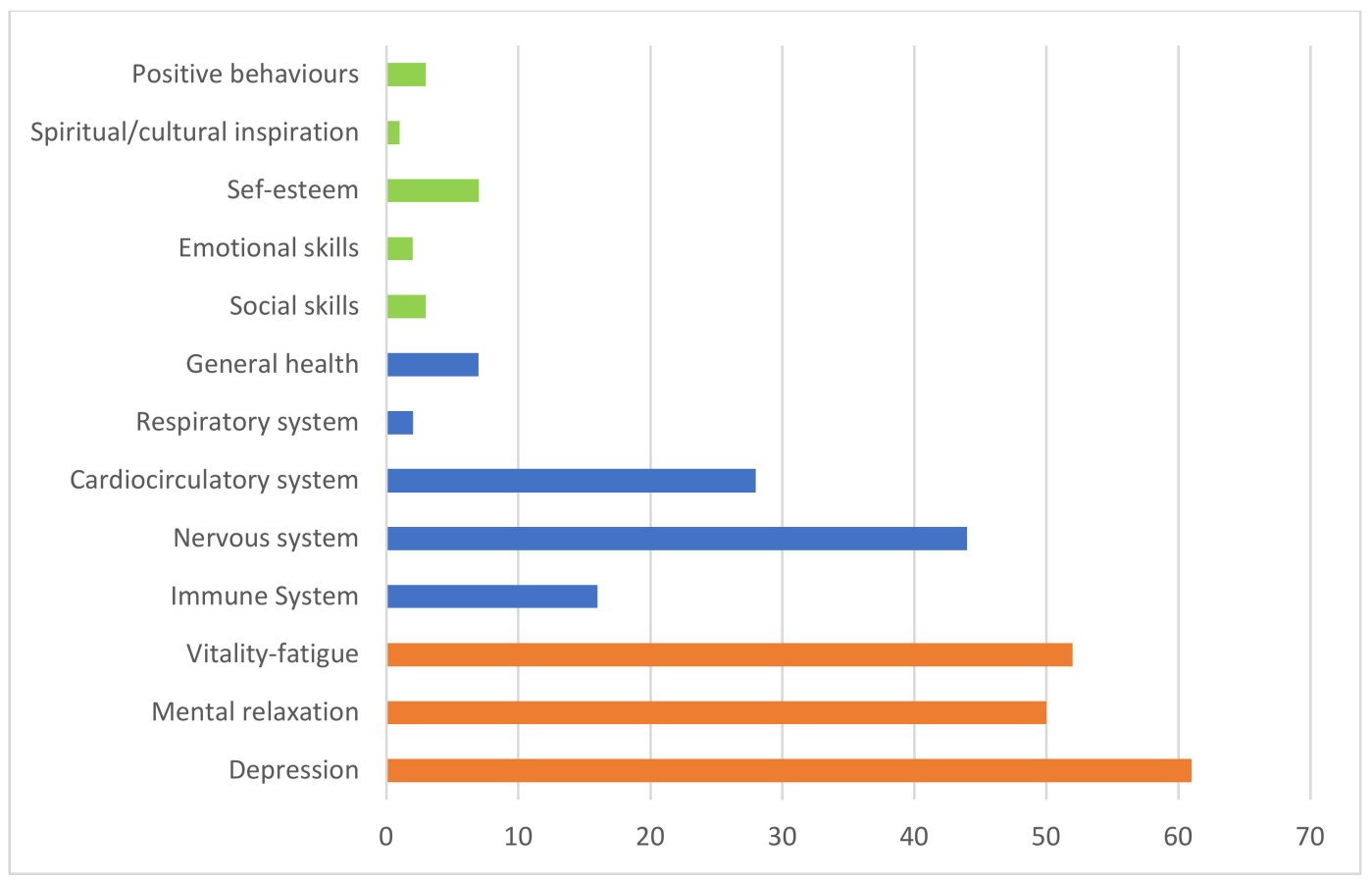

Figure 3. Number of papers in which the specific effects of forest-based initiatives are assessed as statistically significant ${ }^{*}$, divided by subcategories of effects (i.e., green for social, blue for physiological and orange for psychological effects) ${ }^{*}$ level of significance is established by each single paper.

\subsection{Effects on Health and Wellbeing}

The review has revealed a stronger focus on psychological and physiological effects of forest contact initiatives and, within the physiological effects, those on the nervous system are by far the most investigated (58\%). Fewer studies have paid attention to social wellbeing effects. A possible explanation for this is that psychological and physiological effects are more easily translated into quantitative data, while social wellbeing effects are less easy to quantify and are mainly assessed via qualitative interviews through multiple forest-based sessions.

In general, according to the majority of studies, even brief contact of a healthy subject with the forest ecosystem can hold more positive wellbeing effects if compared to the same experience in an urban environment. This confirms the Kaplan \& Kaplan [71] theory which posits that it is more probable that people experience restoration with higher intensity in a natural than in an urban environment. Nevertheless, the review has also found uncertainty on this issue, since changes in wellbeing after a contact with the forest ecosystem were found to be statistically nonsignificant in thirteen studies for psychological effects and eighteen studies for physiological effects.

Studies investigating wellbeing effects of contact with the forest ecosystem focus their attention on assessing the decreasing level (or symptoms) of stress perceived by body and mind. Stress is the reaction of the body to a real or perceived harmful situation, or when facing daily tasks and demands that require an effort exceeding the available resources of a person. A stressful situation induces both cognitive and physiological responses in order to cope. Therefore, stress is perceived at both psychological and physiological levels and involves a systemic response of the body that might reflect on physical health. Indeed, the human body is not equipped to sustain prolonged stress conditions and when this happens (chronic stress), NCD may arise. A forest-based experience triggers a chain of reactions activating the parasympathetic nervous system, which is usually activated by situations of relaxation and produces relaxing effects on mind and body [72]. Indeed, psychological and physiological effects are often observed together when addressing direct contact with forest ecosystems. A visit to a forest can influence psychological responses via the senses and decrease the subjectively perceived effects of stress [73-75], depression, anxiety and negative emotions [75-77], 
while increasing a sense of vigour, recovery and positive feelings [78]. Activity of the parasympathetic nervous system can also be associated with physiological effects, for example, a decreasing heart rate can be measured as a proxy biomarker of nervous system relaxation [79,80]. Furthermore, a decrease in the levels of concentration of stress-hormones such as cortisol, adrenaline and noradrenaline, reveal activation of the endocrine system [81-85]. It is also found that a forest visit might increase immune function [86-88] in comparison to nonexposed subjects within control-groups. Another effect on the immune system is observable in terms of increasing number and activity of Natural Killer Cells (NKcells) and levels of intracellular anti-cancer proteins [89-93]. Indeed, some studies reveal that adrenaline and noradrenaline inhibit human NKcells activity, therefore a visit to a forest, by decreasing levels of psycho-physiological stress, might boost the immune system [94,95]. Positive anti-cancer adjuvant effects were also found for women with breast-cancer after traditional treatment [96]. Some of these studies suggest that positive effects on the immune system are correlated with the presence of terpenes in the forest atmosphere and thus the reduction of stress hormones [35,89]. Terpenes are volatile organic compounds (VOCs) produced by plants that can be found in essential oils and are present in the forest atmosphere in different types and quantities depending on the plant species and climatic conditions $[35,97]$.

A specific parameter often considered to measure cardiovascular benefits after a forest experience is decreasing level of blood pressure $[73,79,98]$, or increasing level of blood oxygenation (i.e., peripheral oxygen saturation) [72]. Pulmonary function also seems improved in people exposed to a forest experience $[99,100]$.

Among the general health benefits for physical wellbeing, improved sleep effects $[39,101,102]$ were observed together with positive effects on metabolism [103]. Forest interventions, by making people feel more comfortable, more vital and positive, may also support positive social wellbeing, including improved self-esteem and health and promoting positive behaviours towards environment and health, e.g., in undergraduate students and children after FT programmes [104,105]. Support of social skills and self-healing process (increasing self-esteem) were also observed among middle-aged women involved in an urban FT programme [106]. This process of healing, through several steps and shifts of participants feelings towards the environment, other participants and finally self, occurs thanks to a process of identification with nature that allows time to reflect and recover [106,107].

Despite differences in the numbers, it is worth stressing that the effects of forest visits or FT are considered nonspecific health effects [31,32]. Namely, a visit to a forest can lead to a general improvement of wellbeing, relaxing both mind and body and enhancing the immune system, but of course it cannot be compared to the specific effects of, for example, an antibiotic.

The authors are aware of the extreme complexity of the bidirectional interactions that occur between the nervous, endocrine and immune systems and concerning how these are correlated to health. To this end, the Psychoneuroimmunology approach may help to deepen understanding on how additional characteristics such as natural environment, personality traits, emotions, lifestyle and socio-economic conditions might influence interactions with natural environments such as forests and provoke changes in health and wellbeing [108,109].

\subsection{Interactions with the Forest and Time Spent}

The typologies of interaction with the forest environment are varied, and range from a simple walk, to the enjoyment of the silence and natural atmosphere in solitude, to organized group activities to engage one's social skills. Literature reveals that forests are suitable for relaxing and reconnecting to the inner-self, for performing energy intensive or adrenalin physical activities or for achieving achieve restoration. According to the Attention Restoration Theory, specific qualities of the experience are needed [110]: for instance, being away from routine mental contexts while experiencing effortless attention (fascination) in an environment that encourages feeling totally immersed, comfortable and at ease (extent) when one's demands and expectations are matched and supported by the environment (compatibility). In order to meet these criteria and experience more intense restoration, the theory 
suggests to engage in well-known activities which do not require the learning of new skills [111]. Indeed, according to the literature, simple forest-based initiatives are the most used to assess wellbeing effects with active interactions such as walking or doing physical exercise in the forest $(n=36)$, or more passive interactions, such as staying still to observe the forest or being exposed to a forest atmosphere with no further specification $(n=22)$. In addition to the fact that walking and simply looking is possible in both forest and urban environments and, with the exception of specific health conditions, these activities demand low physical and mental effort, this might partially explain the reason why such activities are extensively implied in experiments with positive results. Instead, organized activities such as FB $(n=7)$ and FT $(n=23)$, are used in about $30 \%$ of the papers analysing direct interaction with forest ecosystems. Eight studies used a combination of two types of interactions, which in all cases are a combination of simple activities.

From the perspective of practitioners, planners and forest managers, it may be useful to understand if there is a specific correlation between different typologies of interaction or between frequency and the time spent on forest visits and wellbeing effects. The review findings reveal that few studies compare and assess the effects of different types of activity and frequencies of visits on health parameters. Specifically, meditative walks are reported to increase subjective happiness more than athletic walks when performed in the same environment, and in general meditative walks in a forest environment are the most effective in increasing perceived happiness [112]. Dealing specifically with elderly subjects, a comparison between a forest walking programme and a forest meditation programme, resulted in both being effective in helping dementia prevention [113]. A forest walk with elevation gain or that is demanding in terms of physical exercise may increase physiological stress but is found to have positive effects in relieving mental stress and feeling uplifted [81]. Furthermore, one study tested the effectiveness of a combination of FB alone and FB with additional physical exercise on people with chronic posterior neck pain, showing a reduction in the number of trigger points after FB and exercise session [114]. In addition, an afternoon forest walk was found to be more effective in extending sleep duration than a forenoon walk in a sample of people with sleep complaints [102]. Jeon et al. [115] is the only study in the review comparing the effects of direct and indirect exposure to a forest, showing how both experiences have positive influences on mental wellbeing, yet indirect experience fails to significatively activate the parasympathetic nerve activity (physiological relaxation).

Looking at the connection between frequency of visits and wellbeing effects, an extensive study on a Japanese population monitored blood pressure and hypertension in relation to forest visits. The results did not find any correlation between frequencies of visits to forest environments and prevalence of hypertension [116]. On the contrary, it was reported that high frequency users of forest environments are less stressed than low frequency users [117] and that going a second time for FB trips may have added benefits in elderly patients with chronic heart failure [118]. Especially in the case of people suffering from depression and severe exhaustion or anxiety, there is a need to familiarize themselves with the environment and have the chance to find a place in the forest according to personal needs and moods (e.g., a quiet and safe spot to experience time in solitude and relief from social pressure to restore mind and emotional resources) $[39,48]$. Feelings are likely to evolve if the subjects are allowed to become acquainted with the forest environment, therefore single-visits might not be effective especially for people experiencing mental and stress-related disorders [119].

Surprisingly, the reviewed studies seem to show that there is very little attention towards assessing the amount of time that can maximize the health benefits on the one hand and, on the other, the long-term effects of forest-based initiatives. However, the optimal "dose" of exposure has been investigated in the literature dealing with exposure to nature and outdoor green in general, suggesting the existence of effective time thresholds beyond which there are no additional benefits [120,121]. Regarding the possibility of the persistence of wellbeing benefits in the long-term, few studies monitored the effects days after the forest experience. These studies reveal that after three days of FT, physiological and psychological effects lasted for 8 weeks [85], positive effects on depression on postmenopausal women 
for 4 weeks [79], increased NKcells activity for 7 days [90,92], decrease in blood pressure for 3 and 5 days and relaxation effects for 3 to 5 days after two days of FT [122].

\subsection{Forest Features}

In this section, the main findings on the effects of specific forest features (i.e., season, settings and management related) on human wellbeing are presented. They are systematized and summarized in Table 2. Forest and landscape literature studies show how different preference patterns exist among forest users and highlight that environmental perception is not a static but a dynamic process mediated by psychological structures and cognitive processes [52]. Different forest settings, management practices and forest elements may therefore provoke different psychological reactions and, hence, different psychological, physiological and social wellbeing effects [26]. However, this issue is rather unexplored in the literature, as only 14 of the studies reviewed in this paper focus on changes in wellbeing effects when there are variations in the forest settings, management practices or when comparing forests with other natural environments.

Field studies report data such as humidity, temperature, light, etc., mainly for methodological reasons concerning the reproducibility of the study [52]. However, this information is not used for therapy-oriented forest management choices. Just one study clearly relates restoration effects of the forest with environmental factors like air temperature, relative humidity, radiant heat, wind speed and thermal comfort [123]. An et al. [124] found that FB may not always benefit visitors' physiology, for example, if they feel too cool, excessive moisture and an extremely high green to blue light ratio in the forest.

The influence of season on health is investigated in just one study, where simple exposure to a broadleaved forest revealed better psychological restorative effects during the winter than in springtime [125]. Other studies, although not directly aimed at comparing seasonal effects on health, confirmed a substantial emotional, restorative, and vitalizing effect on the participants by visiting forests during winter with snow [126,127], during autumn [128,129] and during spring, also activating physiological relaxation [130]. Joung et al. [129] confirmed wellbeing effects of looking at a forest landscape (rather than an urban one) from the top of a building during autumn. This may suggest that features such as leaf colors, presence of snow or variability in light levels in the forest influence the perceived restoration and consequent effects on health, but evidence is scarce. Research on season-specific effects on human wellbeing and the identification of corresponding forest features responsible for such effects should be further developed in this sense. In addition to this, the two abovementioned studies conducted during winter are based in Poland where it is legitimate to suppose that the population is also used to visiting forests during winter, hence studies should clarify the influence of custom and cultural backgrounds on wellbeing effects.

Studies on subjects spending the same amount of time (or viewing through virtual reality in the case of Wang et al. [131]) in forest settings characterized by different sensorial features, either natural (presence of a lake, or dead wood) or artificial (presence of benches or platforms), revealed that (i) all forest settings have restorative properties; (ii) the most natural environment does not necessarily have the most significant effect on stress [39,68]; and (iii) water landscapes are generally rated as having greater stress relief capacities. A qualitative study of an FT programme on veterans with post-traumatic stress disorder revealed how the perception and the relationship with the environment change during the therapy [119]. While in woodlands, people tend to identify locations within the given space that meet their needs and feelings in that precise moment (i.e., space for quietness, place with special value, space to create social contact) $[68,119]$. This is why, in FT programmes, multiple sceneries are usually designed to engage the walkers and strengthen their impression on the interaction with nature [39]. In general, it is suggested that a forest setting for therapy intervention should provide a diversity of spaces, balancing enclosure with openness [132] and possibly let people choose by preference [68,133]. This is supported by other studies revealing that the perceived preference for tree diversity may also be influenced by cognitive differences. For example, forest experts may prefer species-rich and natural 
landscapes because they are aware of the importance of biodiversity. In contrast, laypeople may prefer scenery with a single species because it looks orderly [134]. In general, providing the public with information on the ecological role of specific ecosystem features (i.e., dead wood) may positively influence their perception of those elements [135]. Safe experience in the woodland during childhood seems also to positively influence the enjoyment of therapeutic qualities during young adulthood [30]. Information and cognitive engagement seem to influence the therapeutic effect of a forest experience which is attached to the perceived qualities of safety, protection, calmness, low demand but also to age and size of trees and their symbolic features [30]. Safety is an issue that might become a constraint especially for people not familiar with the forest, who might not feel comfortable in having to engage with such an environment (e.g., darkness, isolation, risks linked to hanging or fallen branches, tick borne diseases or wild animals) [136].

Dealing with users' preferences towards management practices, it seems that visitors in general prefer managed forests to fully unmanaged natural forests but also irregular stands with a mixture of trees of different sizes, while a feeling of accessibility and a view seem important $[137,138]$. Some of the papers investigate the possible influence on human wellbeing of aspects linked with forest management practices. In this regard, results show that users' appreciation and perceived wellbeing do not change in the same coniferous forest between managed and unmanaged areas when management regard light thinning removing (corresponding to ca. $10 \%$ of the basal area) [139], while perceived restoration seems to improve with more consistent thinning operations [140]. A Korean study compared effects of a wild and tended forest, finding that while both have positive physiological effects for people with metabolic syndrome, they resulted more intense in the case of the wild forest, for psychological effects as well [141]. 
Table 2. Findings on forest features.

\begin{tabular}{|c|c|c|c|c|}
\hline Forest Feature & Country & Reference & Details on Forest & Effects on Health \\
\hline SEASON & Poland & [125] & $\begin{array}{l}\text { A forest composed of Fagus sylvatica L., pedunculate oak, Quercus } \\
\text { robur L., Alnus glutinosa. Visited in both spring and winter. }\end{array}$ & $\begin{array}{c}\text { During winter effects on wellbeing result better than in } \\
\text { spring. }\end{array}$ \\
\hline \multirow{3}{*}{ SETTINGS } & China & [131] & $\begin{array}{l}\text { Seven different forest environments selected for their restorative } \\
\text { features and shown through pictures to subjects. The seven } \\
\text { environments: (1) structure, (2) wood on the ground, (3) wood on } \\
\text { the ground with bench, (4) wood with platform and bench, (5) } \\
\text { platform with trees, (6) waterfall with trees, (7) pool with plants. }\end{array}$ & $\begin{array}{c}\text { In each setting psychological and physiological effects are } \\
\text { different, in general the experience of looking at them is } \\
\text { positive for physical and mental wellbeing. }\end{array}$ \\
\hline & Sweden & [39] & $\begin{array}{l}\text { A forest-based rehabilitation (22 visits to the forest, twice a week) } \\
\text { to provide rest and solitude, performed in } 8 \text { different forest } \\
\text { settings: (1) forest by lake,(2) rock outcrop, (3) pine forest, (4) } \\
\text { mixed forest, (5) spruce forest, (6) forest with a small creek, (7-8) } \\
\text { two open mires. }\end{array}$ & $\begin{array}{l}\text { Auditive dimension is reported to be fundamental for the } \\
\text { enjoyment and relaxation of the experience. Presence of } \\
\text { water is particularly appreciated in the sensorial } \\
\text { experience. Openness and light are also reported to be } \\
\text { important in determining a positive experience. }\end{array}$ \\
\hline & Sweden & [68] & $\begin{array}{l}\text { Six different forest settings visited by people with severe } \\
\text { exhaustion disorders by their preferences: (1) forest with a lake, } \\
\text { (2) rock outcrop, (3) pine forest, (4) mixed forest, (5) spruce forest, } \\
\text { (6) forest with a small stream. }\end{array}$ & $\begin{array}{l}\text { Positive psychological and social effects in all the settings. } \\
\text { Forest by a lake was the preferred, light was important, } \\
\text { forest brought reminiscences of childhood, associated } \\
\text { forest with rest and no demands, change in scenery and } \\
\text { solitude was appreciated. }\end{array}$ \\
\hline \multirow[b]{2}{*}{ MANAGEMENT } & Japan & [142] & $\begin{array}{l}\text { Managed (thinning operation one year before visit, cutting and } \\
\text { removing } 9.2 \% \text { in basal area of trees) vs. Unmanaged (densely } \\
\text { packed trees, not managed for some decades) forest. }\end{array}$ & $\begin{array}{l}\text { Managed forest may have greater beneficial effect than } \\
\text { unmanaged ones in regard to lowering heart rate ratio, } \\
\text { physiological restoration effects in a managed forest may } \\
\text { be independent of individual traits. On the other hand, } \\
\text { some positive effects may be related to people's individual } \\
\text { traits: dense forest might be more beneficial for people } \\
\text { with tendencies towards depression and neuroticism. }\end{array}$ \\
\hline & $\begin{array}{l}\text { Republic } \\
\text { of Korea }\end{array}$ & [141] & $\begin{array}{l}\text { Wild (Saneum Forest mixed forest covering } 2141 \text { hectares that } \\
\text { consists of larch, fir, and nut pine trees, as well as oak, dogwood, } \\
\text { ash, and birch trees that are over } 30 \text { years old; presence of } \\
\text { drinkable water flow and there are walking trails with varying } \\
\text { degrees of steepness) vs. Managed forests (Seoul forest, an urban } \\
\text { forest established in 2005, } 116 \text { hectares, and consists of oak, } \\
\text { hornbeam, and cherry trees that are over } 10 \text { years old). Mean } \\
\text { concentration of phytoncides in the experimental sites was } \\
\text { significantly higher in the wild forest }\left(25.58 \mathrm{ng} / \mathrm{m}^{3}\right) \text { than in the } \\
\text { tended forest }\left(18.44 \mathrm{ng} / \mathrm{m}^{3}\right) \text {. }\end{array}$ & $\begin{array}{l}\text { Psychological effects on patients with metabolic syndrome } \\
\text { are more pronounced in the wild forest than in the tended } \\
\text { one. }\end{array}$ \\
\hline
\end{tabular}


Table 2. Cont.

\begin{tabular}{|c|c|c|c|c|}
\hline Forest Feature & Country & Reference & Details on Forest & Effects on Health \\
\hline \multirow[t]{5}{*}{ MANAGEMENT } & Japan & [140] & $\begin{array}{c}\text { Thinned (66.3\% Japanese larch (Larix kaempferi), 10.1\% giant } \\
\text { dogwood (Cornus controversa), 7.3\% Japanese red pine (Pinus } \\
\text { densiflora), } 6.4 \% \text { fir trees (Abies spp.), and 9.7\%, other vegetation } \\
\text { depending on the breast height of the basal area in the dense } \\
\text { forest) vs. unthinned forest (66.5\% Japanese larch (Larix kaempferi), } \\
7.0 \% \text { giant dogwood (Cornus controversa), } 7.3 \% \text { Japanese red pine } \\
\text { (Pinus densiflora), } 0.0 \% \text { fir trees (Abies), and } 19.2 \% \text { other } \\
\text { vegetation) }\end{array}$ & $\begin{array}{l}\text { Regarding restorative traits of the forest, no statistically } \\
\text { significant differences between the dense and thinned } \\
\text { forest settings are registered. Feelings marginally improve } \\
\text { in the thinned forest. ROS (Subjective Restorativeness) } \\
\text { scores are higher in thinned forest. }\end{array}$ \\
\hline & Japan & [139] & $\begin{array}{l}\text { Thinned forest with half the amount ( } 15 \text { to } 20 \% \text { ) vs. standard } \\
\text { thinning ( } 30 \text { to } 40 \% \text { ) in forestry regions. }\end{array}$ & $\begin{array}{c}\text { Half the amount of standard forest thinning is enough to } \\
\text { accomplish the management without affecting user's } \\
\text { appreciation and the restorative effect. In general, mood, } \\
\text { anxiety and restoration were improved after the forest } \\
\text { visit. }\end{array}$ \\
\hline & China & [143] & Urban forest vs. rural forest; both with paths and infrastructures & $\begin{array}{c}\text { FB in the urban park tended to be associated with lower } \\
\text { levels of anxieties from social contact (especially } \\
\text { love-affairs). }\end{array}$ \\
\hline & Spain & [144] & $\begin{array}{l}\text { Mature (many centenarian trees with large and irregular shaped } \\
\text { trunk and big roots above the ground; dominant species is sessile } \\
\text { oak, with a harmoniously irregular high mountain structure and } \\
\text { a considerable density of old trees with sizable crowns; rare and } \\
\text { very penetrable undergrowth) vs. young forest (regular and } \\
\text { dense woodland, age range of 5-35 years, without any tree } \\
\text { exceeding } 50 \text { years; dominant species is sessile oak, a small area } \\
\text { of beech trees, with species such as bramble (Rubus ulmifolius), } \\
\text { hawthorn (Crataegus monogyna), or broom (Cytisus scoparius); } \\
\text { vegetation is homogeneous, compact, closed, and less penetrable) }\end{array}$ & $\begin{array}{l}\text { Significant decrease in number of days of intense pain, } \\
\text { insomnia and increase in days of wellbeing only in the } \\
\text { group experiencing the mature forest. No differences were } \\
\text { found with respect to anxiety between the subjects in the } \\
\text { two forests. }\end{array}$ \\
\hline & Finland & [145] & $\begin{array}{l}\text { Urban forest (total size of } 1000 \text { ha, widely used for outdoor } \\
\text { recreation, mainly consists of } 60 \text { to } 100 \text {-year-old mixed and } \\
\text { conifer forests, where the participants viewed spruce-dominated } \\
\text { mature forest stands) vs. urban park ( } 5 \text { ha well-designed green } \\
\text { area with flower beds, water element, lawns, old trees including } \\
\text { facilities such as benches, and a performance stage), both vs. city }\end{array}$ & $\begin{array}{c}\text { Both forest and park have more restorative effects } \\
\text { (measured as perceived stress and salivary cortisol) than } \\
\text { the city. Overall, the forest was better than the park in } \\
\text { some cases }\end{array}$ \\
\hline
\end{tabular}


Table 2. Cont.

\begin{tabular}{|c|c|c|c|c|}
\hline Forest Feature & Country & Reference & Details on Forest & Effects on Health \\
\hline & Japan & [99] & $\begin{array}{l}\text { Species: Volatile Organic Compounds from leaves of Acer } \\
\text { truncatum Bunge (3-hexen-1-ol acetate, 3-hexen-1-ol, acetic acid } \\
\text { hexyl ester), sampled tree was approximately } 5.60 \mathrm{~m} \text { in height } \\
\text { and } 24.5 \mathrm{~cm} \text { in diameter at breast height, and Cedrus deodara } \\
\text { ( } \beta \text {-myrcene, D-limonene, pinene and } \beta \text {-caryophyllene) sampled } \\
\text { tree was approximately } 11.2 \mathrm{~m} \text { in height and had a DBH of } \\
40.5 \mathrm{~cm} \text {. The leaves facing the south were selected in the middle } \\
\text { of the June. }\end{array}$ & $\begin{array}{l}\text { Physiological results indicated cardiovascular, nervous } \\
\text { and neurological relaxation after sniffing VOC from C. } \\
\text { deodara., but no significant effects after smelling A. } \\
\text { truncatum. Smell of C. deodara was associated with natural } \\
\text { feelings and more relaxing than A. truncatum. }\end{array}$ \\
\hline & China & [124] & $\begin{array}{l}\text { Species: oak forest trees taller }(\sim 13 \mathrm{~m}) \text { than those in maple }(\sim 8 \mathrm{~m}) \\
\text { and birch forests }(\sim 12 \mathrm{~m}) \text {, but diameter growth, canopy length, } \\
\text { and canopy cover ratio were all not statistically different among } \\
\text { them. }\end{array}$ & $\begin{array}{l}\text { No effects on blood pressure; maple forests have better } \\
\text { results on cardiovascular and autonomic nervous system } \\
\text { wellbeing. Relationship found between environmental } \\
\text { factors (temperature, RH, light intensity and light } \\
\text { spectrum) and physiological effects: forest contact may } \\
\text { not always benefit visitors' physiology if they felt too cool, } \\
\text { excessive moisture and extremely high G/B light ratio in } \\
\text { the forest. }\end{array}$ \\
\hline & China & [77] & $\begin{array}{l}\text { Species: about } 40 \% \text { of the area is covered by a lake, near which } \\
\text { three pure forests were chosen: birch (Betula platyphylla Suk.), } \\
\text { maple (Acer triflorum Komarov) and oak (Quercus mongolica Fisch. } \\
\text { ex Ledeb). All three forests were planted about } 20 \text { years ago with } \\
\text { similar characteristics }\end{array}$ & $\begin{array}{l}\text { Young adults can perceive the anxiety alleviation in all } \\
\text { three forests, with different characteristics in each. }\end{array}$ \\
\hline
\end{tabular}


The same study by Lee et al. reported that the mean concentration of phytoncides in the wild forest atmosphere was significantly higher than in the tended forest one. However, the concept of "wild forest" must be interpreted with caution, as the wild forest considered in this study is the Saneum Recreational Forest, a model of forest design for health interventions in Korea but certainly not a "wild forest" according to European forest management standards. Looking at managed and unmanaged forests, dense (unmanaged) forest might be more beneficial for people with tendencies towards depression and neuroticism showing a decreased heart rate after a stress stimulus, and physiological restoration effects in a managed forest may be independent of individual traits [142]. The forest used in this experiment is a larch plantation of about 80 years old, where the managed plot was thinned the year before removing around $9 \%$ of basal area, while the other plot had been unmanaged for decades.

A positive correlation between specific tree species and health effects has been found in relation to enhanced cardiovascular and autonomic nervous system wellbeing while walking in a maple forest rather than in birch and oak forests [124]. Two Chinese studies assessed perceived anxiety level changes in university students [143]. Zhou et al., [143] found that rich and dense rural forests were just as efficient as less rich or dense urban forests in lowering perceived anxiety. Guan et al. [77] found a positive correlation between human weight and tree-species-specific effects on anxiety. In these two studies, specific causes of anxiety (i.e., financial state, employment, exam pressure, campus life and romantic relationships) were appraised, suggesting that (i) different forest settings may be more effective than others in alleviating specific types of perceived anxiety. For example, urban forests seem to be more suitable to alleviate anxiety from social contact than nonurban forests; birch forests seem to have better effects for alleviating employment worries than maple and oak, probably due to the relaxing effects of white bark colour and lower stem density of birch trees; and (ii) in general, being able to control tree diversity may help to alleviate general anxiety but improvements are shown in any case when visiting a forest. Studies on visitors' preferences suggest that not every natural ecosystem has restorative properties: for example, very rich and dense wooded ecosystems may increase the feeling of anxiety for the general public [146]. Lopez Pousa et al. [144], in contrast, found no statistically-significant difference in health effects perceived by patients with fibromyalgia between a walk in a mature and a young forest: in both cases, patients felt psycho-physical improvements after the programme. Looking at an urban park and a highly managed conifer urban woodland, Tyirvainen et al. [145] found that walking and resting in a natural environment has more positive effects on stress than in an urban environment and that urban woodlands have slightly more intense effects than a park. We report as a curiosity, since not tested in comparison to other species, two studies investigating the efficacy of exposure specifically to bamboo forest, which are important ecosystems especially in Asian countries [147], finding improvement in blood pressure, and in general in improving mood and anxiety states in comparison to nonexposed subjects (control group) $[93,148]$.

\subsection{Sensorial Dimension of the Forest Ecosystem}

Forest visitors, even if without a specific background in forestry or ecosystem services, perceive the forest ecosystem through the five senses [149]: for instance, the presence of light filtering through the leaves or through the scenery (visual), through the smell of moss and other plants (olfactory), through the sound of leaves moved by the wind or the presence of a river (auditory), the sensation of different types of soils under the feet (tactile) and the taste of fresh air (taste). However, while the psycho-physiological effects of single sensory inputs can be elucidated only by controlled laboratory settings, field studies cannot isolate the single sensory inputs provided by a forest setting. This explains the limited information available on specific elements of the scenery responsible for wellbeing changes: just $32 \%$ of the papers associate a specific forest element (e.g., season, management practices, species composition and diversity, sensorial features, etc.) with wellbeing effects.

It is known that engagement of all the senses during a forest experience enhances relaxation and restoration potential of the environment [32,110]. Vision is the sense primarily involved in triggering psychological and physiological effects in field studies with direct contact with the forest ecosystem. 
Sensory information captured by receptors are processed by the corresponding areas of the brain and then transmitted through interactions of sensory inputs. This information reaches the associated area of the brain where it triggers emotional and physical reactions [52]. Such psycho-physical interrelations are made marginally visible in one study investigating the effects of viewing and not viewing (obscured by a curtain) the forest while directly in contact with the ecosystem [150]. Indeed, there is no significant difference between the two experimental conditions, meaning that both the cardiocirculatory and nervous systems reacted positively to being immersed in a forest atmosphere (physiological relaxation), while subjective psychological relaxation (POMS scores) improved just when subjects were able to see the forest [150]. This suggests that psychological relaxation (at least some of its components) might be more dependent on visual than physiological stimulation. These results are confirmed by a study where psychological effects are achieved just after viewing a forest picture, whereas physiological improvement happened regardless of viewing an urban or a forest picture [79]. One study using visual stimulation found significant psychological and physiological relaxation effects after viewing forest pictures instead of urban ones [151]. Interestingly, one study made people choose their preferred landscape, resulting in significative positive physiological and psychological effects both looking at forest and seascapes, depending on people's preferences [133]. Wang et al. [131] conducted a stress-related study by having individuals look at pictures of seven different existing forests, selected for different restorative properties. They found a general stress-relief effect for all the images and that different forest settings have different types of effects on relieving stress.

The sense of vision is the most investigated among studies, but changes in wellbeing state are reported also with reference to olfactory, tactile, auditory and taste stimuli. Touching wood with the palm, induces, in comparison to other materials, a more intense physiological relaxation by calming prefrontal cortex activity and activating parasympathetic nervous activity [152]. The forest atmosphere is loaded with VOCs emitted by plants, which can be absorbed through inhaling or ingesting them. Positive physiological effects have been found inhaling Hinoki cypress leaf oil (Chamaecyparis obtusa) [153], Acer truncatum and Cedrus deodara, where the smell of C. deodara was associated with more natural and relaxing feelings than $A$. truncatum [99]. Combined stimuli of viewing a landscape of Hinoki cypress trees and smelling Hinoki cypress leaf essential oil showed to have additive benefits both on physiological and psychological relaxation, compared to single sensorial stimuli and control tests [154]. For more details on VOCs from forest plants refer to Cho et al. [35]. One study tested the effects of ingesting eucalyptus essential oil, largely used in aromatherapy, showing positive physiological (decrease of salivary cortisol levels) relaxation effects [155]. Lastly, one study included in this review monitored the effects of urban and forest sounds using sounds of a murmuring brook in Togakushi forest in Nagano Prefecture and traffic sounds at the Shibuya intersection in Tokyo [69]. Forest sounds positively contributed to both psychological (i.e., greater feeling of "comfortable," "relaxed," "natural", and improved mood states) and physiological relaxation by decreasing prefrontal cortex activity and activating parasympathetic nervous activity.

\subsection{Individual Traits and Pre-Existence of Specific Health Conditions}

Studies on landscape preferences and perception already suggested that individual cognitive and emotional processes, interacting with biological and cultural ones, might influence people's preferences towards one environment over another [27,156]. Two studies, referring specifically to forest visits used for rehabilitation from stress-related exhaustion [68] and video relaxation therapy [133], reported that individual preferences seem to be effective in maximizing health benefits. Limited emergences from the literature seem to point out how people's individual traits might affect psychological and physiological responses to a forest experience. For example, different behavioural patterns or psycho-physiological traits of participants might explain individual differences related to effects on health before and after a forest experience, such as differences in cortisol level after ingesting essential oil [155], in pulse rate and blood pressure changes after staring at a forest environment [157] or in different brain and nervous 
response to different activities [113]. Contrarily, one study claimed a low influence of individual traits indicators on restorative indicators [158].

A number of studies investigate effects of forest exposure on subjects with specific pre-existing health conditions, showing that experiences and walks in the forest might be an effective and cost-saving integrative therapy for multiple diseases, disorders and chronic conditions. With regard to mental health pre-conditions such as depressive tendencies, some studies revealed that the higher the acute feelings (stress or trait anxiety levels), the greater the positive effects of a forest walk $[74,75,158,159]$. Similarly, effects of forest visits result higher for people with depressive tendencies than for people without, and as mentioned in Table 2, physiological restoration effects in a managed forest may be independent of individual traits [142]. Effects of FT may diminish depression level in alcoholics [160], in people with post-traumatic stress disorder [119] and in people with severe exhaustion disorders, even if the latter might experience increased stress and discomfort when they are taken to the forest for the first time $[39,68]$. These evidences suggest that in several cases the pre-existence of specific mental health conditions influence the final wellbeing effects of a forest experience. Looking at health preconditions linked to physiological wellbeing, both walks and visits to a forest might have positive effects on hypertensive and elderly patients in terms of reducing blood pressure, pro-inflammatory factors, decreasing heart rate and increasing parasympathetic nerve activity and positive mood $[70,85,88,161]$. Walking and having multiple visits in the forest atmosphere can be beneficial for elderly people with chronic heart failure by inhibiting the renin-angiotensin system resulting in decreased blood pressure and pro-inflammatory effects, which are prominent factors in the development and maintenance of hypertensive chronic heart failure $[87,88,118,162,163]$. Meditation and walking activities in the forest rather than in an urban environment seem to be more effective for treating depression and anxiety symptoms in patients with chronic stroke [76], and in general these activities seem to be useful to prevent dementia and Alzheimer's disease [124]. Forest experiences also seem to alleviate respiratory conditions through improved function of the immune system of elderly patients with chronic obstructive pulmonary disease [164]. This means forest-based interventions might be considered effective prevention instruments for hypertension, chronic respiratory diseases and dementia in a section of the population at risk (i.e., the elderly) and promoting forest walks might help in maintaining under control the population already at risk. A couple of studies suggest that walks and relaxing activities in the forest might improve the general sense of wellbeing, depression and decrease pain and insomnia in patients with fibromyalgia [144] and with chronic wide-spread pain [165]. Moreover, forest visits may have positive effects on people with sleep complaints [101,102], on quality of life and stress also in postmenopausal women [166], in patients with breast-cancer receiving traditional therapy [96] and in patients with metabolic syndrome [141].

On the other hand, this implies that with further studies it may be possible to identify particular ecosystems and activities that are more efficient than others in tackling specific health conditions.

\subsection{Proposed Pathways from Forest to Wellbeing}

Evidence from the reviewed papers shows that target beneficiaries, outcomes and forest settings vary widely, from healthy adults to people with specific diseases, from promotion of wellbeing to integrated treatment of stress-related exhaustion and from highly tended urban forests to species-rich rural ones. Results suggest that forests are a multifaceted resource promoting health and wellbeing, integrated into people's daily life increasing access to wellbeing-as is the case of urban forestsand/or providing a natural escape from cities.

In the attempt to link the medical and forest research and to propose effective pathways from forest to wellbeing, the effects of contact with forest and its elements on people's health resulting from the review can be clustered in three groups: (i) the different types of interactions and activities carried out within the forest; (ii) the individual reaction to the experience and individual needs and; (iii) the different forest features which can affect interaction, also through forest management of the sensorial dimensions. The effects that originate at the individual level act at the psychological, physiological and 
social levels to improve wellbeing. From this level of action, forest-based interventions can scale-up by being integrated into policy and decision making in order to maximize and scale up the beneficial effects of forest exposure. When shifting from individual to community level, health promotion, prevention and treatment or rehabilitation interventions according to the target beneficiaries are introduced, and this in turn influences public health and wellbeing. To this end, a conceptualization of the pathways linking forests to public health and wellbeing is proposed, which integrates previous work by Markevych et al. [167], Hartig [36], Miyazaki et al. [31], Song et al. [17] and Shanahan et al. [13]. This conceptualization focuses on the purposes and outcomes of interventions (Figure 4).

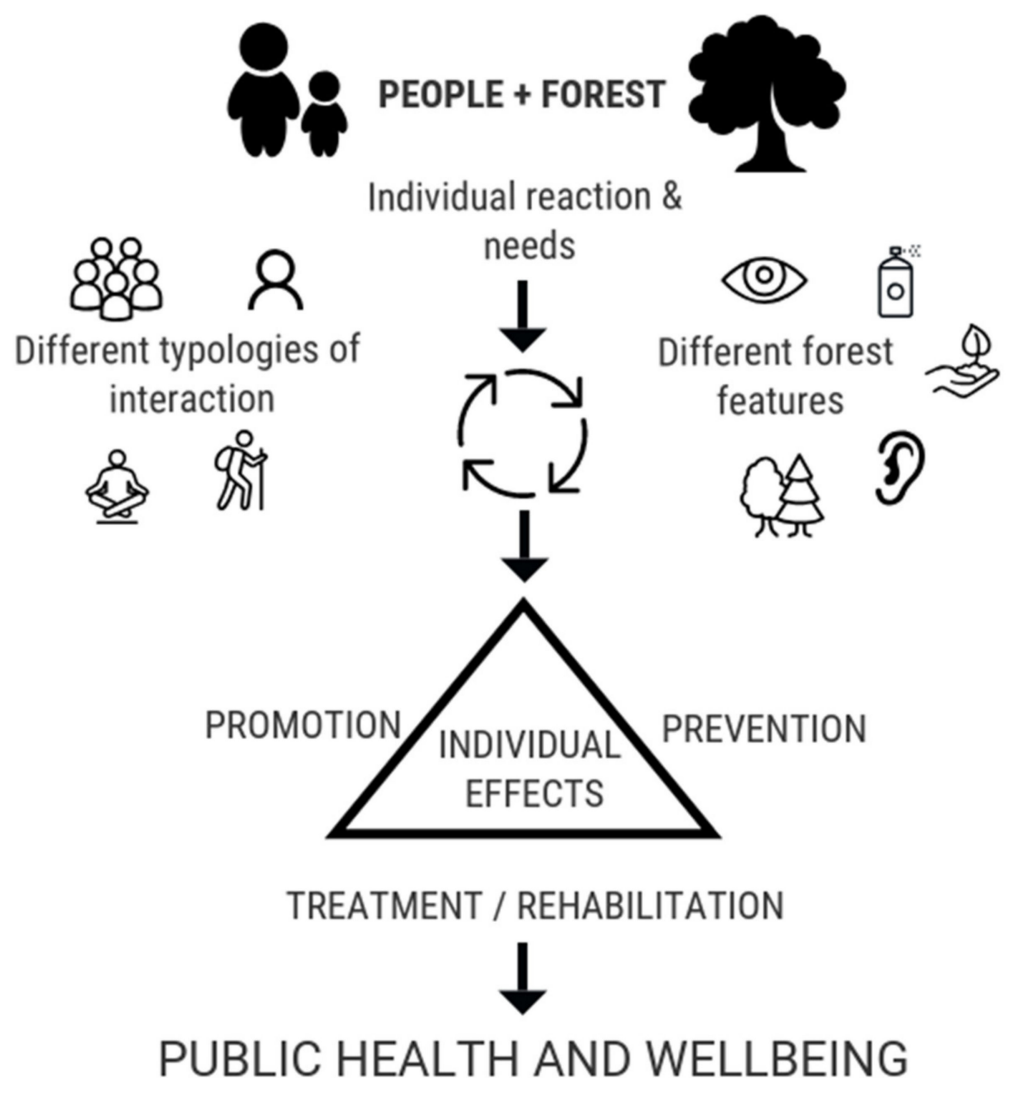

Figure 4. Pathways from forest experiences to public health and wellbeing.

From a forestry point of view, the framework indicates that it is possible to act fully on the variables of group (i) and, though to a more limited extent, also on those of group (ii). Forest management practices can obviously influence many visible and nonvisible features of the forest ecosystem that can be perceived by the five senses, thereby affecting wellbeing outcomes. For example, tree-species composition may determine the type and amount of VOCs emitted, while supporting the presence of specific bird species affects the sounds which can be heard in the forest. Nevertheless, isolating specific effects of silvicultural practices is challenging, while results of Section 3.5 have shown that laboratory studies isolating single sensorial stimuli allow specific forest-wellbeing connections to be clearly identified; being in the forest is a holistic experience engaging all senses, mind and body.

With reference to the different possible types of interactions between people and forest ecosystem, there is limited room for action by forest managers alone. This variable involves organizational, management and policy aspects beyond the sole forest dimension, revealing strong connections with other sectors, such as public health, urban and landscape planning, among others. Furthermore, this variable reminds us of the need to look at the demand side, being able to acknowledge people's needs and preferences. In this sense, the last group of variables-i.e., the individual reaction and need-is totally focused on the beneficiaries of forest-based interventions and mainly falls within 
the domain of health and wellbeing science. Hence, an integrated and interdisciplinary approach is needed to support effective forest-based intervention aimed at increasing health and wellbeing in people.

\section{Conclusions}

This paper provides a review of scientific publications in the field of human health and wellbeing deriving from contacts with forests. Findings allow it to be argued that forest-based initiatives in general have a "health bonus" in respect to other initiatives carried out in urban environments. In this sense, urban forests and urban and peri-urban wooded areas which are easily accessible for a great number of people, will have a crucial role in the sustainable development of cities not just by making cities more resilient to climate change but also by providing a quality occasion for stimulating inactive population, fighting stress and improving wellbeing in general. Nevertheless, there is the need to fill knowledge gaps and to consider the methodological and informative limits of the available empirical studies. This is also important with respect to the growing attention this topic is originating among the public and civil society, creating a multitude of local level initiatives in some cases without strong scientific basis but rather driven by intuition and personal skills (e.g., personal or business coaching, yoga, meditation). As a possible concurring cause of this, there is the fact that research methodologies in the health sector are highly demanding in terms of resources which are not always available in environmental sector initiatives and projects. Nevertheless, mixing a scientific with non-scientific approach might lead to the risk of diluting the efficacy and huge potential of these initiatives both for health and environmental impacts. Human health and ecosystem management are multifaceted and complex domains by their very nature and overly simplistic approaches to them should be avoided. This includes disregarding a "one fits all" approach but designing and adapting each forest intervention with a multidisciplinary approach that considers all the variables that might affect the final results. All the aspects need attention and research efforts in order to plan, manage and deliver effective forest-based interventions for wellbeing by enhancing forest visits as a tool for health promotion and prevention. With this review we provide an overview of this emerging field highlighting gaps and starting to create a common framework to bridge different disciplines involved to support the development of integrated solutions.

Despite our efforts, the review has some limitations, including publication bias such as possible positive-results bias as authors are more likely to submit, and editors and publishers more attracted towards positive and significant results, creating a dominant discourse around the benefits of forests for human health. This tendency is most probably influenced by the momentum that this topic currently has, yet in the next years negative, inconsistent results and different hypothesis will arguably find more space in the research agenda. Furthermore, little space is given to investigating effects of time, frequency, type of activity and participants' previous relationship with the forest. Since information is still scattered across a multitude of different disciplines and fields of research with scarce dialogue, and the topic of forests as places for wellbeing is still evolving, this review may not cover all its aspects and nuances. Nonetheless, this is a first attempt to collect and systematize the available information and identify the boundaries of such a topic. Of course, limiting the review to the literature on health effects rather than including, for example, that on preferences, determines a prevalence of medicine-related studies but also allows gaps and research needs bridging forestry-related studies to be identified. For example, present evidence-based medicine studies lack the support of forestry research and data to determine whether a particular forest (e.g., tree species composition) or environmental feature (e.g., microclimate or VOCs) have specific benefits. Further, there is a lack of consideration for synergic effects of the numerous features composing a forest ecosystem that are simultaneously experienced by all the "five senses". Interesting information would have been a distinction between urban, peri-urban and rural forests. Lastly, the literature and practice of forest experience for wellbeing is recent and this makes identification of an appropriate set of keyworks able to include all types of possible interactions with the forest, its atmosphere and elements, difficult. 
With regard to gaps in the literature and future research needs, it is clear that more interdisciplinary studies are required. The lack of clear terminology, umbrella definition and classification of forest-based activities for wellbeing might be an additional obstacle to the disciplines' dialogue and cooperation. Furthermore, since most experiments are conducted in Asian countries, the transferability is not straightforward. In the first instance, tree species, forest ecosystems and urban forest and woodlands are profoundly different. Secondly, we have seen how the final effects on wellbeing can be shaped by preferences and target group needs and expectations but also to the extent of attraction, the meaning attached and the engagement with the place $[136,168]$. Therefore, there is a need to engage more research also in European and culturally diverse countries, possibly using wider samples, testing the effects of multiple visits to the forest and long-term effects. Future research should also clearly assess whether geographical origin and cultural background of the subjects might influence subjective and objective measured health effects of a forest experience. Well-designed empirical and qualitative studies might help in better defining the role of cultural background on individual reactions and capturing the complexity of the forest-human relationship [23].

The evidence presented here raises the issue on how to positively influence wellbeing effects in practice through management choices and operations. It will be necessary to both explore artificial/indoor stimuli and new techniques-such as the use of a photoionization detector for investigating the variability, in time and space, of the concentration of total VOCs [97] —and be able to assimilate them into new integrated approaches. In this light, risks and disbenefits (e.g., from safety to wildfire and vector-borne diseases) should also be considered in future research. This knowledge will have implications on forest management, planning and design, and help to enhance the cooperation between health, forestry and landscape planning sectors. This would also help in evaluating specific competencies involved, avoiding mystification and speculative approaches to health and wellbeing. Reinforced in the light of the recent health emergency due to the pandemic spread of Covid-19 and the social distancing measures applied worldwide, the potential of indoor and virtual stimuli to deliver forest benefits is an option with increasing relevance.

In addition, we have seen how peer-reviewed studies assessing social benefits are marginalized in the literature reviewed, together with qualitative studies. Filling this research gap about social health impacts of forest experiences and understanding how to maximize them might create synergies with the growing commitment of cities and metropolises around the world towards afforestation and urban forestry planning, by supporting the delivery of other ecosystem services, e.g., biodiversity conservation, climate change adaptation and resilience of urban ecosystems. Furthermore, a better understanding of the opportunities to positively affect social wellbeing through contact with the forest ecosystem, will be more and more strategic in an increasingly urbanized and ageing population. Focusing on the information available, this scoping review can be useful to define parameters to develop more specific systematic reviews that help to fill the knowledge gap mentioned.

Supplementary Materials: The following is available online at http://www.mdpi.com/1999-4907/11/8/791/s1, Table S1: Overview of literature review on forest-based initiatives and wellbeing effects.

Author Contributions: Database searches, application of inclusion criteria, analyses and original draft preparation, I.D.; study design, and methodology definition, I.D., M.M. and P.G.; review and editing, P.G. and M.M.; supervision, M.M. and P.G. All authors have read and agreed to the published version of the manuscript.

Funding: This research received no external funding.

Conflicts of Interest: The authors declare no conflict of interest. 


\section{References}

1. World Federation for Mental Health. DEPRESSION: A Global Crisis; World Mental health Day, October 10; World Federation for Mental Health: Occoquan, VA, USA, 2012.

2. Ahmed, M.Z.; Ahmed, O.; Aibao, Z.; Hanbin, S.; Siyu, L.; Ahmad, A. Epidemic of COVID-19 in China and associated Psychological Problems. Asian J. Psychiatr. 2020, 51. [CrossRef]

3. Rossi, R.; Socci, V.; Talevi, D.; Mensi, S.; Niolu, C.; Pacitti, F.; Di Marco, A.; Rossi, A.; Siracusano, A.; Di Lorenzo, G. COVID-19 pandemic and lockdown measures impact on mental health among the general population in Italy. An N=18147 web-based survey. medRxiv 2020. (pre-print). [CrossRef]

4. O'Donovan, M.R.; Gapp, C.; Stein, C. Burden of disease studies in the WHO European Region-a mapping exercise. Eur. J. Public Health 2018, 28, 773-778. [CrossRef] [PubMed]

5. James, S.L.; Abate, D.; Abate, K.H.; Abay, S.M.; Abbafati, C.; Abbasi, N.; Abbastabar, H.; Abd-Allah, F.; Abdela, J.; Abdelalim, A.; et al. Global, regional, and national incidence, prevalence, and years lived with disability for 354 Diseases and Injuries for 195 countries and territories, 1990-2017: A systematic analysis for the Global Burden of Disease Study 2017. Lancet 2018, 392, 1789-1858. [CrossRef]

6. Nilsson, K.; Sangster, M.; Gallis, C.; Hartig, T.; Vries, S.; Seeland, K.; Schipperijn, J. Forests, Trees and Human Health; Springer Netherlands: Dordrecht, The Nerthland, 2011; ISBN 9789048198054.

7. Corazon, S.S.; Sidenius, U.; Poulsen, D.V.; Gramkow, M.C.; Stigsdotter, U.K. Psycho-physiological stress recovery in outdoor nature-based interventions: A systematic review of the past eight years of research. Int. J. Environ. Res. Public Health 2019, 16. [CrossRef] [PubMed]

8. Kondo, M.C.; Jacoby, S.F.; South, E.C. Does spending time outdoors reduce stress? A review of real-time stress response to outdoor environments. Heal. Place 2018, 51, 136-150. [CrossRef]

9. Norwood, M.F.; Lakhani, A.; Fullagar, S.; Maujean, A.; Downes, M.; Byrne, J.; Stewart, A.; Barber, B.; Kendall, E. A narrative and systematic review of the behavioural, cognitive and emotional effects of passive nature exposure on young people: Evidence for prescribing change. Landsc. Urban. Plan. 2019, 189, 71-79. [CrossRef]

10. Lakhani, A.; Norwood, M.; Watling, D.P.; Zeeman, H.; Kendall, E. Using the natural environment to address the psychosocial impact of neurological disability: A systematic review. Heal. Place 2019, 55, 188-201. [CrossRef]

11. Kuo, M.; Barnes, M.; Jordan, C. Do experiences with nature promote learning? Converging evidence of a cause-and-effect relationship. Front. Psychol. 2019, 10. [CrossRef]

12. Bowler, D.E.; Buyung-Ali, L.M.; Knight, T.M.; Pullin, A.S. A systematic review of evidence for the added benefits to health of exposure to natural environments. BMC Public Health 2010, 10. [CrossRef]

13. Shanahan, D.F.; Astell-Burt, T.; Barber, E.A.; Brymer, E.; Cox, D.T.C.; Dean, J.; Depledge, M.; Fuller, R.A.; Hartig, T.; Irvine, K.N.; et al. Nature-Based Interventions for Improving Health and Wellbeing: The Purpose, the People and the Outcomes. Sports 2019, 7, 141. [CrossRef] [PubMed]

14. Westlund, S. Becoming human again': Exploring connections between nature and recovery from stress and post-traumatic distress. Work 2015, 50, 161-174. [CrossRef] [PubMed]

15. Van den Bosch, M. Ode Sang Urban natural environments as nature-based solutions for improved public health-A systematic review of reviews. Environ. Res. 2017, 158, 373-384. [CrossRef]

16. Seymour, V. The human-nature relationship and its impact on health: A critical review. Front. Public Heal. 2016, 4, 260. [CrossRef] [PubMed]

17. Song, C.; Ikei, H.; Miyazaki, Y. Physiological effects of nature therapy: A review of the research in Japan. Int. J. Environ. Res. Public Health 2016, 13. [CrossRef] [PubMed]

18. Wen, Y.; Yan, Q.; Pan, Y.; Gu, X.; Liu, Y. Medical empirical research on forest bathing (Shinrin-yoku): A systematic review. Environ. Health Prev. Med. 2019, 24. [CrossRef]

19. Karjalainen, E.; Sarjala, T.; Raitio, H. Promoting human health through forests: Overview and major challenges. Environ. Health Prev. Med. 2010, 15, 1. [CrossRef]

20. Nilsson, K.; Sangster, M.; Gallis, C.; Hartig, T.; Vries, S.; Seeland, K.; Schipperijn, J. Forests, trees and human health. For. Trees Hum. Heal. 2011, 1-427. [CrossRef]

21. Chun, H.-Y.Y.; Newman, R.; Whiteley, W.N.; Dennis, M.; Mead, G.E.; Carson, A.J. A systematic review of anxiety interventions in stroke and acquired brain injury: Efficacy and trial design. J. Psychosom. Res. 2018, 104, 65-75. [CrossRef] 
22. Hansen, M.M.; Jones, R.; Tocchini, K. Shinrin-yoku (Forest bathing) and nature therapy: A state-of-the-art review. Int. J. Environ. Res. Public Health 2017, 14, 851. [CrossRef]

23. Oh, B.; Lee, K.J.; Zaslawski, C.; Yeung, A.; Rosenthal, D.; Larkey, L.; Back, M. Health and well-being benefits of spending time in forests: Systematic review. Environ. Health Prev. Med. 2017, 22. [CrossRef] [PubMed]

24. Cervinka, R.; Höltge, J.; Pirgie, L.; Schwab, M.; Sudkamp, J.; Haluza, D.; Arnberger, A.; Eder, R.; Ebenberger, M.; Lackner, C.; et al. Green Public Health-Benefits of Woodlands on Human Health and Well-being (Zur Gesundheitswirkung von Waldlandschaften); Bundesforschungszentrum für Wald (BFW): Vienna, Austria, 2014; ISBN 978-3-902762-32-0.

25. Lee, J.; Park, B.-J.; Tsunetsugu, Y.; Miyazaki, Y. Forests and Human Health-Recent Trends in Japan; Nova Science Publishers: Hauppauge, NY, USA, 2013; ISBN 9781626184626.

26. Shin, W.S.; Yeoun, P.S.; Yoo, R.W.; Shin, C.S. Forest experience and psychological health benefits: The state of the art and future prospect in Korea. Environ. Health Prev. Med. 2010, 15, 38-47. [CrossRef] [PubMed]

27. Hartig, T.; Staats, H. The need for psychological restoration as a determinant of environmental preferences. J. Environ. Psychol. 2006, 26, 215-226. [CrossRef]

28. Ulrich, R.S.; Simons, R.F.; Losito, B.D.; Fiorito, E.; Miles, M.A.; Zelson, M. Stress recovery during exposure to natural and urban environments. J. Environ. Psychol. 1991, 11, 201-230. [CrossRef]

29. Hartig, T.; Staats, H. Guest Editors' introduction: Restorative environments. J. Environ. Psychol. 2003, 23, 103-107. [CrossRef]

30. Milligan, C.; Bingley, A. Restorative places or scary spaces? The impact of woodland on the mental well-being of young adults. Heal. Place 2007, 13, 799-811. [CrossRef]

31. Miyazaki, Y.; Lee, J.; Park, B.J.; Tsunetsugu, Y.; Matsunaga, K. Preventive medical effects of nature therapy. Nihon Eiseigaku Zasshi. 2011, 66, 651-656. [CrossRef]

32. Miyazaki, Y.; Ikei, H.; Song, C. Forest medicine research in Japan. Nihon Eiseigaku Zasshi. 2014, 69, 122-135. [CrossRef]

33. Park, B.J.; Tsunetsugu, Y.; Kasetani, T.; Kagawa, T.; Miyazaki, Y. The physiological effects of Shinrin-yoku (taking in the forest atmosphere or forest bathing): Evidence from field experiments in 24 forests across Japan. Environ. Health Prev. Med. 2010, 15, 18-26. [CrossRef]

34. Li, Q.; Nakadai, A.; Matsushima, H.; Miyazaki, Y.; Krensky, A.; Kawada, T.; Morimoto, K. Phytoncides (wood essential oils) induce human natural killer cell activity. Immunopharmacol Immunotoxicol. 2006, 28, 319-333. [CrossRef]

35. Cho, K.S.; Lim, Y.-R.; Lee, K.; Lee, J.; Lee, J.H.; Lee, I.-S. Terpenes from forests and human health. Toxicol. Res. 2017, 33, 97-106. [CrossRef] [PubMed]

36. Hartig, T.; Mitchell, R.; de Vries, S.; Frumkin, H. Nature and Health. Annu. Rev. Public Health 2014, 35, $207-228$. [CrossRef] [PubMed]

37. Farrow, M.R.; Washburn, K. A Review of Field Experiments on the Effect of Forest Bathing on Anxiety and Heart Rate Variability. Glob. Adv. Heal. Med. 2019, 8, 216495611984865. [CrossRef] [PubMed]

38. Lee, I.; Choi, H.; Bang, K.-S.; Kim, S.; Song, M.K.; Lee, B. Effects of forest therapy on depressive symptoms among adults: A systematic review. Int. J. Environ. Res. Public Health 2017, 14. [CrossRef]

39. Sonntag-Öström, E.; Stenlund, T.; Nordin, M.; Lundell, Y.; Ahlgren, C.; Fjellman-Wiklund, A.; Järvholm, L.S.; Dolling, A. "Nature's effect on my mind"-Patients' qualitative experiences of a forest-based rehabilitation programme. Urban. For. Urban. Green. 2015, 14. [CrossRef]

40. Rosa, C.D.; Collado, S. Experiences in nature and environmental attitudes and behaviors: Setting the ground for future research. Front. Psychol. 2019, 10, 763. [CrossRef]

41. Dadvand, P.; Hariri, S.; Abbasi, B.; Heshmat, R.; Qorbani, M.; Motlagh, M.E.; Basagaña, X.; Kelishadi, R. Use of green spaces, self-satisfaction and social contacts in adolescents: A population-based CASPIAN-V study. Environ. Res. 2019, 168, 171-177. [CrossRef]

42. Sandifer, P.A.; Sutton-Grier, A.E.; Ward, B.P. Exploring connections among nature, biodiversity, ecosystem services, and human health and well-being: Opportunities to enhance health and biodiversity conservation. Ecosyst. Serv. 2015, 12, 1-15. [CrossRef]

43. Dean, J.; van Dooren, K.; Weinstein, P. Does biodiversity improve mental health in urban settings? Med. Hypotheses 2011, 76, 877-880. [CrossRef]

44. Haluza, D.; Schönbauer, R.; Cervinka, R. Green perspectives for public health: A narrative review on the physiological effects of experiencing outdoor nature. Int. J. Environ. Res. Public Health 2014. [CrossRef] 
45. O'Brien, L.; Morris, J.; Stewart, A. Engaging with Peri-Urban Woodlands in England: The Contribution to People's Health and Well-Being and Implications for Future Management. Int. J. Environ. Res. Public Health 2014, 11, 6171-6192. [CrossRef] [PubMed]

46. Aerts, R.; Honnay, O.; Van Nieuwenhuyse, A. Biodiversity and human health: Mechanisms and evidence of the positive health effects of diversity in nature and green spaces. Br. Med. Bull. 2018, 127, 5-22. [CrossRef]

47. Kondo, M.C.; Fluehr, J.M.; McKeon, T.; Branas, C.C. Urban green space and its impact on human health. Int. J. Environ. Res. Public Health 2018, 15, 445. [CrossRef] [PubMed]

48. O'Brien, L. Engaging with and Shaping Nature: A Nature-Based Intervention for Those with Mental Health and Behavioural Problems at the Westonbirt Arboretum in England. Int. J. Environ. Res. Public Health 2018, 15, 2214. [CrossRef] [PubMed]

49. Kamioka, H.; Tsutani, K.; Mutoh, Y.; Honda, T.; Shiozawa, N.; Okada, S.; Park, S.-J.; Kitayuguchi, J.; Kamada, M.; Okuizumi, H.; et al. A systematic review of randomized controlled trials on curative and health enhancement effects of forest therapy. Psychol. Res. Behav. Manag. 2012, 5, 85-95. [CrossRef] [PubMed]

50. Li, Q. Effect of forest bathing trips on human immune function. Environ. Health Prev. Med. 2010, 15, 9-17. [CrossRef]

51. Ikei, H.; Song, C.; Miyazaki, Y. Physiological effects of wood on humans: A review. J. Wood Sci. 2017, 63. [CrossRef]

52. Tsunetsugu, Y.; Park, B.-J.; Miyazaki, Y. Trends in research related to "shinrin-yoku" (taking in the forest atmosphere or forest bathing) in Japan. Environ. Health Prev. Med. 2010, 15, 27-37. [CrossRef]

53. Bach Pagès, A.; Peñuelas, J.; Clarà, J.; Llusià, J.; Campillo i López, F.; Maneja, R. How Should Forests Be Characterized in Regard to Human Health? Evidence from Existing Literature. Int. J. Environ. Res. Public Health 2020, 17, 1027. [CrossRef]

54. Peters, M.D.J.; Godfrey, C.M.; Khalil, H.; McInerney, P.; Parker, D.; Soares, C.B. Guidance for conducting systematic scoping reviews. Int. J. Evid. Based. Healthc. 2015, 13, 141-146. [CrossRef]

55. Munn, Z.; Peters, M.D.J.; Stern, C.; Tufanaru, C.; McArthur, A.; Aromataris, E. Systematic review or scoping review? Guidance for authors when choosing between a systematic or scoping review approach. BMC Med. Res. Methodol. 2018, 18, 143. [CrossRef] [PubMed]

56. Arksey, H.; O’Malley, L. Scoping studies: Towards a methodological framework. Int. J. Soc. Res. Methodol. Theory Pract. 2005, 8, 19-32. [CrossRef]

57. Levac, D.; Colquhoun, H.; O’Brien, K.K. Scoping studies: Advancing the methodology. Implement. Sci. 2010, 5, 69. [CrossRef]

58. WHO. Available online: https://www.who.int/about/who-we-are/constitution (accessed on 3 March 2020).

59. Albert, L.; Stanciu, C.; Delcea, C.; Mihai, A.; Popșor, S. Psycho-emotional Factors and Their Role in Craniomandibular Disorders. Int. J. Ment. Heal. Psychiatry 2018, 4. [CrossRef]

60. Maas, J.; van Dillen, S.M.E.; Verheij, R.A.; Groenewegen, P.P. Social contacts as a possible mechanism behind the relation between green space and health. Heal. Place 2009, 15, 586-595. [CrossRef] [PubMed]

61. Sempik, J.; Aldridge, J. Health, Well-Being and Social Inclusion: Therapeutic Horticulture in the UK; Policy Press: Bristol, UK, 2005.

62. Jay, M.; Schraml, U. Understanding the role of urban forests for migrants - uses, perception and integrative potential. Urban. For. Urban. Green. 2009, 8, 283-294. [CrossRef]

63. Haines-Young, R.; Potschin, M. Common International Classification of Ecosystem Services (CICES) V5.1 Guidance on the Application of the Revised Structure. Eur. Environ. Agency 2018, 53.

64. Fish, R.; Church, A.; Winter, M. Conceptualising cultural ecosystem services: A novel framework for research and critical engagement. Ecosyst. Serv. 2016. [CrossRef]

65. Cooper, N.; Brady, E.; Steen, H.; Bryce, R. Aesthetic and spiritual values of ecosystems: Recognising the ontological and axiological plurality of cultural ecosystem "services. " Ecosystem Services 2017, 21, 218-229. [CrossRef]

66. Fish, R.; Church, A.; Willis, C.; Winter, M.; Tratalos, J.A.; Haines-Young, R.; Potschin, M. Making space for cultural ecosystem services: Insights from a study of the UK nature improvement initiative. Ecosyst. Serv. 2016, 21, 329-343. [CrossRef] 
67. Morita, E.; Kadomatsu, Y.; Tsukamoto, M.; Kubo, Y.; Okada, R.; Sasakabe, T.; Kawai, S.; Hishida, A.; Naito, M.; Wakai, K. Frequency of forest walking is not associated with prevalence of hypertension based on cross-sectional studies of a general Japanese population: A reconfirmation by the J-MICC Daiko Study. Nagoya J. Med. Sci. 2019, 81, 489-500. [CrossRef]

68. Sonntag-öStrö, E.; Nordin, M.; Järvholm, L.S.; Lundell, Y.; Brännström, R.; Dolling, A. Can the boreal forest be used for rehabilitation and recovery from stress-related exhaustion? a pilot study. Scand. J. For. Res. 2011, 26, 245-256. [CrossRef]

69. Jo, H.; Song, C.; Ikei, H.; Enomoto, S.; Kobayashi, H.; Miyazaki, Y. Physiological and psychological effects of forest and urban sounds using high-resolution sound sources. Int. J. Environ. Res. Public Health 2019, 16. [CrossRef] [PubMed]

70. Song, C.; Ikei, H.; Kobayashi, M.; Miura, T.; Li, Q.; Kagawa, T.; Kumeda, S.; Imai, M.; Miyazaki, Y. Effects of viewing forest landscape on middle-aged hypertensive men. Urban. For. Urban. Green. 2017, 21, $247-252$. [CrossRef]

71. The Experience of Nature: A Psychological Perspective-Rachel Kaplan, Stephen Kaplan—Google Books. Available online: https://books.google.it/books?hl=en\&lr=\&id=7180AAAAIAAJ\&oi=fnd\&pg=PR7\&ots= TpP_RFocZg\&sig=bNNbNM6vHW-AG2Q8DdWZIN6IEcU\&redir_esc=y\#v=onepage\&q\&f=false (accessed on 17 March 2020).

72. Lyu, B.; Zeng, C.; Xie, S.; Li, D.; Lin, W.; Li, N.; Jiang, M.; Liu, S.; Chen, Q. Benefits of a three-day bamboo forest therapy session on the psychophysiology and immune system responses of male college students. Int. J. Environ. Res. Public Health 2019, 16. [CrossRef]

73. Chen, H.-T.; Yu, C.-P.; Lee, H.-Y. The effects of forest bathing on stress recovery: Evidence from middle-aged females of Taiwan. Forests 2018, 8. [CrossRef]

74. Morita, E.; Fukuda, S.; Nagano, J.; Hamajima, N.; Yamamoto, H.; Iwai, Y.; Nakashima, T.; Ohira, H.; Shirakawa, T. Psychological effects of forest environments on healthy adults: Shinrin-yoku (forest-air bathing, walking) as a possible method of stress reduction. Public Health 2007, 121, 54-63. [CrossRef] [PubMed]

75. Song, C.; Ikei, H.; Park, B.J.; Lee, J.; Kagawa, T.; Miyazaki, Y. Psychological benefits of walking through forest areas. Int. J. Environ. Res. Public Health 2018, 15. [CrossRef]

76. Chun, M.H.; Chang, M.C.; Lee, S.-J. The effects of forest therapy on depression and anxiety in patients with chronic stroke. Int. J. Neurosci. 2017, 127, 199-203. [CrossRef]

77. Guan, H.; Wei, H.; He, X.; Ren, Z.; An, B. The tree-species-specific effect of forest bathing on perceived anxiety alleviation of young-adults in urban forests. Ann. For. Res. 2017, 60, 327-341. [CrossRef]

78. Takayama, N.; Korpela, K.; Lee, J.; Morikawa, T.; Tsunetsugu, Y.; Park, B.J.; Li, Q.; Tyrväinen, L.; Miyazaki, Y.; Kagawa, T. Emotional, restorative and vitalizing effects of forest and urban environments at four sites in Japan. Int. J. Environ. Res. Public Health 2014, 11, 7207-7230. [CrossRef] [PubMed]

79. Yu, C.-P.; Lin, C.-M.; Tsai, M.-J.; Tsai, Y.-C.; Chen, C.-Y. Effects of short forest bathing program on autonomic nervous system activity and mood states in middle-aged and elderly individuals. Int. J. Environ. Res. Public Health 2017, 14. [CrossRef]

80. Lee, J.; Tsunetsugu, Y.; Takayama, N.; Park, B.-J.; Li, Q.; Song, C.; Komatsu, M.; Ikei, H.; Tyrväinen, L.; Kagawa, T.; et al. Influence of forest therapy on cardiovascular relaxation in young adults. Evid.-Based Complement. Altern. Med. 2014, 2014. [CrossRef] [PubMed]

81. Toda, M.; Den, R.; Hasegawa-Ohira, M.; Morimoto, K. Effects of woodland walking on salivary stress markers cortisol and chromogranin A. Complement. Ther. Med. 2013, 21, 29-34. [CrossRef] [PubMed]

82. Ochiai, H.; Ikei, H.; Song, C.; Kobayashi, M.; Takamatsu, A.; Miura, T.; Kagawa, T.; Li, Q.; Kumeda, S.; Imai, M.; et al. Physiological and psychological effects of forest therapy on middle-aged males with high-normal blood pressure. Int. J. Environ. Res. Public Health 2015, 12, 2532-2542. [CrossRef] [PubMed]

83. Ochiai, H.; Ikei, H.; Song, C.; Kobayashi, M.; Miura, T.; Kagawa, T.; Li, Q.; Kumeda, S.; Imai, M.; Miyazaki, Y.; et al. Physiological and psychological effects of forest therapy on middle-aged Female. Int. J. Environ. Res. Public Health 2015, 12, 15222-15232. [CrossRef]

84. Kobayashi, H.; Song, C.; Ikei, H.; Park, B.J.; Lee, J.; Kagawa, T.; Miyazaki, Y. Population-based study on the effect of a forest environment on salivary cortisol concentration. Int. J. Environ. Res. Public Health 2017, 14. [CrossRef] 
85. Sung, J.; Woo, J.M.; Kim, W.; Lim, S.K.; Chung, E.J. The effect of cognitive behavior therapy-based "forest therapy" program on blood pressure, salivary cortisol level, and quality of life in elderly hypertensive patients. Clin. Exp. Hypertens. 2012, 34, 1-7. [CrossRef]

86. Mao, G.X.; Lan, X.G.; Cao, Y.B.; Chen, Z.M.; He, Z.H.; Lv, Y.D.; Wang, Y.Z.; Hu, X.L.; Wang, G.F.; Yan, J. Effects of short-term forest bathing on human health in a broad-leaved evergreen forest in Zhejiang Province, China. Biomed. Environ. Sci. 2012, 25, 317-324. [CrossRef]

87. Wu, Q.; Cao, Y.; Mao, G.; Wang, S.; Fang, Y.; Tong, Q.; Huang, Q.; Wang, B.; Yan, J.; Wang, G. Effects of forest bathing on plasma endothelin-1 in elderly patients with chronic heart failure: Implications for adjunctive therapy. Geriatr. Gerontol. Int. 2017, 17, 2627-2629. [CrossRef]

88. Mao, G.-X.; Cao, Y.-B.; Lan, X.-G.; He, Z.-H.; Chen, Z.-M.; Wang, Y.-Z.; Hu, X.-L.; Lv, Y.-D.; Wang, G.-F.; Yan, J. Therapeutic effect of forest bathing on human hypertension in the elderly. J. Cardiol. 2012, 60, 495-502. [CrossRef] [PubMed]

89. Li, Q.; Morimoto, K.; Nakadai, A.; Inagaki, H.; Katsumata, M.; Shimizu, T.; Hirata, Y.; Hirata, K.; Suzuki, H.; Miyazaki, Y.; et al. Forest bathing enhances human natural killer activity and expression of anti-cancer proteins. Int. J. Immunopathol. Pharmacol. 2007, 20, 3-8. [CrossRef] [PubMed]

90. Li, Q.; Morimoto, K.; Kobayashi, M.; Inagaki, H.; Katsumata, M.; Hirata, Y.; Hirata, K.; Suzuki, H.; Li, Y.J.; Wakayama, Y.; et al. Visiting a forest, but not a city, increases human natural killer activity and expression of anti-cancer proteins. Int. J. Immunopathol. Pharmacol. 2008, 21, 117-127. [CrossRef] [PubMed]

91. Park, B.-J.; Tsunetsugu, Y.; Ishii, H.; Furuhashi, S.; Hirano, H.; Kagawa, T.; Miyazaki, Y. Physiological effects of Shinrin-yoku (taking in the atmosphere of the forest) in a mixed forest in Shinano Town, Japan. Scand. J. For. Res. 2008, 23, 278-283. [CrossRef]

92. Li, Q.; Morimoto, K.; Kobayashi, M.; Inagaki, H.; Katsumata, M.; Hirata, Y.; Hirata, K.; Shimizu, T.; Li, Y.J.; Wakayama, Y.; et al. A forest bathing trip increases human natural killer activity and expression of anti-cancer proteins in female subjects. J. Biol. Regul. Homeost. Agents 2008, 22, 45-55.

93. Lyu, B.; Zeng, C.; Deng, S.; Liu, S.; Jiang, M.; Li, N.; Wei, L.; Yu, Y.; Chen, Q. Bamboo forest therapy contributes to the regulation of psychological responses. J. For. Res. 2019, 24, 61-70. [CrossRef]

94. Garland, M.; Doherty, D.; Golden-Mason, L.; Fitzpatrick, P.; Walsh, N.; O’Farrelly, C. Stress-related hormonal suppression of natural killer activity does not show menstrual cycle variations: Implications for timing of surgery for breast cancer. Anticancer Res. 2003, 23, 2531-2535.

95. Yokota, T.; Uehara, K.; Nomoto, Y. Addition of noradrenaline to intrathecal morphine augments the postoperative suppression of natural killer cell activity. J. Anesth. 2004, 18, 190-195. [CrossRef]

96. Kim, B.J.; Jeong, H.; Park, S.; Lee, S. Forest adjuvant anti-cancer therapy to enhance natural cytotoxicity in urban women with breast cancer: A preliminary prospective interventional study. Eur. J. Integr. Med. 2015, 7, 474-478. [CrossRef]

97. Meneguzzo, F.; Albanese, L.; Bartolini, G.; Zabini, F. Temporal and spatial variability of volatile organic compounds in the forest atmosphere. Int. J. Environ. Res. Public Health 2019, 16. [CrossRef]

98. Song, C.; Ikei, H.; Miyazaki, Y. Sustained effects of a forest therapy program on the blood pressure of office workers. Urban. For. Urban. Green. 2017, 27, 246-252. [CrossRef]

99. Song, X.; Li, H.; Li, C.; Xu, J.; Hu, D. Effects of VOCs from leaves of Acer truncatum Bunge and Cedrus deodara on human physiology and psychology. Urban. For. Urban. Green. 2016, 19, 29-34. [CrossRef]

100. Lee, J.Y.; Lee, D.C. Cardiac and pulmonary benefits of forest walking versus city walking in elderly women: A randomised, controlled, open-label trial. Eur. J. Integr. Med. 2014, 6, 5-11. [CrossRef]

101. Kawada, T.; Li, Q.; Nakadai, A.; Inagaki, H.; Katsumata, M.; Shimizu, T.; Hirata, Y.; Hirata, K.; Suzuki, H. Effect of Forest Bathing on Sleep and Physical Activity. In Forest Medicine; Nova Science Publisher: Hauppauge NY, USA, 2012; pp. 105-110, ISBN 978-1-62100-000-6.

102. Morita, E.; Imai, M.; Okawa, M.; Miyaura, T.; Miyazaki, S. A before and after comparison of the effects of forest walking on the sleep of a community-based sample of people with sleep complaints. Biopsychosoc. Med. 2011, 5. [CrossRef]

103. Li, Q.; Kobayashi, M.; Kumeda, S.; Ochiai, T.; Miura, T.; Kagawa, T.; Imai, M.; Wang, Z.; Otsuka, T.; Kawada, T. Effects of Forest Bathing on Cardiovascular and Metabolic Parameters in Middle-Aged Males. Evid.-Based Complement. Altern. Med. 2016, 2016. [CrossRef] 
104. Bang, K.S.; Lee, I.; Kim, S.; Lim, C.S.; Joh, H.K.; Park, B.J.; Song, M.K. The effects of a campus Forest-Walking program on undergraduate and graduate students' physical and psychological health. Int. J. Environ. Res. Public Health 2017, 14. [CrossRef]

105. Bang, K.S.; Kim, S.; Song, M.K.; Kang, K.I.; Jeong, Y. The effects of a health promotion program using urban forests and nursing student mentors on the perceived and psychological health of elementary school children in vulnerable populations. Int. J. Environ. Res. Public Health 2018, 15. [CrossRef]

106. Lee, H.J.; Son, Y.H.; Kim, S.; Lee, D.K. Healing experiences of middle-aged women through an urban forest therapy program. Urban. For. Urban. Green. 2019, 38, 383-391. [CrossRef]

107. Oh, K.H.; Shin, W.S.; Khil, T.G.; Kim, D.J. Six-step model of nature-based therapy process. Int. J. Environ. Res. Public Health 2020, 17. [CrossRef]

108. França, K.; Lotti, T.M. Psycho-neuro-endocrine-immunology: A psychobiological concept. In Advances in Experimental Medicine and Biology; Springer New York LLC: New York, NY, USA, 2017; Volume 996, pp. 123-134.

109. González-Díaz, S.N.; Arias-Cruz, A.; Elizondo-Villarreal, B.; Monge-Ortega, O.P. Psychoneuroimmunoendocrinology: Clinical implications. World Allergy Organ. J. 2017, 10, 19. [CrossRef]

110. Kaplan, S. The restorative benefits of nature: Toward an integrative framework. J. Environ. Psychol. 1995, 15, 169-182. [CrossRef]

111. Daniel, R. The Effects of the Natural Environment On Attention Restoration; Appalachian State University: Boone, NC, USA, 2014.

112. Shin, Y.K.; Kim, D.J.; Jung-Choi, K.; Son, Y.J.; Koo, J.W.; Min, J.A.; Chae, J.H. Differences of psychological effects between meditative and athletic walking in a forest and gymnasium. Scand. J. For. Res. 2013, 28, 64-72. [CrossRef]

113. Yi, J.; Ku, B.; Kim, S.G.; Khil, T.; Lim, Y.; Shin, M.; Jeon, S.; Kim, J.; Kang, B.; Shin, J.; et al. Traditional korean medicine-based forest therapy programs providing electrophysiological benefits for elderly individuals. Int. J. Environ. Res. Public Health 2019, 16. [CrossRef] [PubMed]

114. Kang, B.; Kim, T.; Kim, M.J.; Lee, K.H.; Choi, S.; Lee, D.H.; Kim, H.R.; Jun, B.; Park, S.Y.; Lee, S.J.; et al. Relief of chronic posterior neck pain depending on the type of forest therapy: Comparison of the therapeutic effect of forest bathing alone versus forest bathing with exercise. Ann. Rehabil. Med. 2015, 39, 957-963. [CrossRef]

115. Jeon, J.Y.; Yeon, P.S.; Shin, W.S. The influence of indirect nature experience on human system. Forest Sci. Technol. 2018, 14, 29-32. [CrossRef]

116. Morita, E.; Naito, M.; Hishida, A.; Wakai, K.; Mori, A.; Asai, Y.; Okada, R.; Kawai, S.; Hamajima, N. No association between the frequency of forest walking and blood pressure levels or the prevalence of hypertension in a cross-sectional study of a Japanese population. Environ. Health Prev. Med. 2011, 16, 299-306. [CrossRef]

117. Jung, W.H.; Woo, J.M.; Ryu, J.S. Effect of a forest therapy program and the forest environment on female workers' stress. Urban. For. Urban. Green. 2015, 14, 274-281. [CrossRef]

118. Mao, G.X.; Cao, Y.B.; Yang, Y.; Chen, Z.M.; Dong, J.H.; Chen, S.S.; Wu, Q.; Lyu, X.L.; Jia, B.B.; Yan, J.; et al. Additive Benefits of Twice Forest Bathing Trips in Elderly Patients with Chronic Heart Failure. Biomed. Environ. Sci. 2018, 31, 159-162. [CrossRef]

119. Poulsen, D.V.; Stigsdotter, U.K.; Djernis, D.; Sidenius, U. 'Everything just seems much more right in nature': How veterans with post-traumatic stress disorder experience nature-based activities in a forest therapy garden. Heal. Psychol. Open 2016, 3. [CrossRef]

120. Shanahan, D.F.; Bush, R.; Gaston, K.J.; Lin, B.B.; Dean, J.; Barber, E.; Fuller, R.A. Health Benefits from Nature Experiences Depend on Dose. Sci. Rep. 2016, 6. [CrossRef]

121. White, M.P.; Alcock, I.; Grellier, J.; Wheeler, B.W.; Hartig, T.; Warber, S.L.; Bone, A.; Depledge, M.H.; Fleming, L.E. Spending at least 120 minutes a week in nature is associated with good health and wellbeing. Sci. Rep. 2019, 9. [CrossRef] [PubMed]

122. Ohe, Y.; Ikei, H.; Song, C.; Miyazaki, Y. Evaluating the relaxation effects of emerging forest-therapy tourism: A multidisciplinary approach. Tour. Manag. 2017, 62, 322-334. [CrossRef]

123. Park, B.-J.; Furuya, K.; Kasetani, T.; Takayama, N.; Kagawa, T.; Miyazaki, Y. Relationship between psychological responses and physical environments in forest settings. Landsc. Urban. Plan. 2011, 102, $24-32$. [CrossRef] 
124. An, B.Y.; Wang, D.; Liu, X.J.; Guan, H.M.; Wei, H.X.; Ren, Z. Bin The effect of environmental factors in urban forests on blood pressure and heart rate in university students. J. For. Res. 2019, 24, 27-344. [CrossRef]

125. Bielinis, E.; Omelan, A.; Boiko, S.; Bielinis, L. The restorative effect of staying in a broad-leaved forest on healthy young adults in winter and spring. Balt. For. 2018, 24, 218-227.

126. Bielinis, E.; Takayama, N.; Boiko, S.; Omelan, A.; Bielinis, L. The effect of winter forest bathing on psychological relaxation of young Polish adults. Urban. For. Urban. Green. 2018, 29, 276-283. [CrossRef]

127. Bielinis, E.; Łukowski, A.; Omelan, A.; Boiko, S.; Takayama, N. The Effect of Recreation in a Snow-Covered Forest Environment on the Psychological Relaxation of Young Females. Forests 2019, 10, 1-15. [CrossRef]

128. Song, C.; Ikei, H.; Igarashi, M.; Takagaki, M.; Miyazaki, Y. Physiological and psychological effects of a walk in Urban parks in fall. Int. J. Environ. Res. Public Health 2015, 12, 14216-14228. [CrossRef]

129. Joung, D.; Kim, G.; Choi, Y.; Lim, H.; Park, S.; Woo, J.-M.; Park, B.-J. The prefrontal cortex activity and psychological effects of viewing forest landscapes in Autumn season. Int. J. Environ. Res. Public Health 2015, 12, 7235-7243. [CrossRef]

130. Song, C.; Ikei, H.; Igarashi, M.; Miwa, M.; Takagaki, M.; Miyazaki, Y. Physiological and psychological responses of young males during spring-time walks in urban parks. J. Physiol. Anthropol. 2014, 33. [CrossRef]

131. Wang, X.; Shi, Y.; Zhang, B.; Chiang, Y. The influence of forest resting environments on stress using virtual reality. Int. J. Environ. Res. Public Health 2019, 16. [CrossRef] [PubMed]

132. Pálsdóttir, A.M. The Role of Nature in Rehabilitation for Individuals with Stress-Related Mental Disorders: Alnarp Rehabilitation Garden as Supportive Environment. Ph.D. Thesis, Dept. of Work Science, Business Economics and Environmental Psychology, Swedish University of Agricultural Sciences, Uppsala, Sweeden, 22 May 2014.

133. Tsutsumi, M.; Nogaki, H.; Shimizu, Y.; Stone, T.E.; Kobayashi, T. Individual reactions to viewing preferred video representations of the natural environment: A comparison of mental and physical reactions. Jpn. J. Nurs. Sci. 2017, 14, 3-12. [CrossRef] [PubMed]

134. Hofmann, M.; Gerstenberg, T.; Gillner, S. Predicting tree preferences from visible tree characteristics. Eur. J. For. Res. 2017, 136, 421-432. [CrossRef]

135. Gundersen, V.; Frivold, L.H. Naturally dead and downed wood in Norwegian boreal forests: Public preferences and the effect of information. Scand. J. For. Res. 2011, 26, 110-119. [CrossRef]

136. Morris, J.; O’Brien, E.; Ambrose-Oji, B.; Lawrence, A.; Carter, C.; Peace, A. Access for all? Barriers to accessing woodlands and forests in Britain. Local Environ. 2011, 16, 375-396. [CrossRef]

137. Daniel, T.C. Public Preferences for Future Conditions in Disturbed and Undisturbed Northern Forest Sites. In The Public and Wildland Fire Management: Social Science Findings for Managers; McCaffrey, S., Ed.; Department of Agriculture, Forest Service, Northern Research Station: Newtown Square, PA, USA, 2006.

138. Gundersen, V.S.; Frivold, L.H. Public preferences for forest structures: A review of quantitative surveys from Finland, Norway and Sweden. Urban. For. Urban. Green. 2008, 7, 241-258. [CrossRef]

139. Takayama, N.; Saito, H.; Fujiwara, A.; Horiuchi, M. The effect of slight thinning of managed coniferous forest on landscape appreciation and psychological restoration. Prog. Earth Planet. Sci. 2017, 4, 17. [CrossRef]

140. Takayama, N.; Fujiwara, A.; Saito, H.; Horiuchi, M. Management effectiveness of a secondary coniferous forest for landscape appreciation and psychological restoration. Int. J. Environ. Res. Public Health 2017, 14. [CrossRef]

141. Lee, K.J.; Hur, J.; Yang, K.-S.; Lee, M.-K.; Lee, S.-J. Acute Biophysical Responses and Psychological Effects of Different Types of Forests in Patients With Metabolic Syndrome. Environ. Behav. 2018, 50, 298-323. [CrossRef]

142. Saito, H.; Horiuchi, M.; Takayama, N.; Fujiwara, A. Effects of managed forest versus unmanaged forest on physiological restoration from a stress stimulus, and the relationship with individual traits. J. For. Res. 2019, 24, 77-85. [CrossRef]

143. Zhou, C.; Yan, L.; Yu, L.; Wei, H.; Guan, H.; Shang, C.; Chen, F.; Bao, J. Effect of Short-term Forest Bathing in Urban Parks on Perceived Anxiety of Young-adults: A Pilot Study in Guiyang, Southwest China. Chin. Geogr. Sci. 2019, 29, 139-150. [CrossRef]

144. López-Pousa, S.; Bassets Pagès, G.; Monserrat-Vila, S.; De Gracia Blanco, M.; Hidalgo Colomé, J.; Garre-Olmo, J . Sense of Well-Being in Patients with Fibromyalgia: Aerobic Exercise Program in a Mature Forest - A Pilot Study. Evid.-Based Complement. Altern. Med. 2015, 2015. [CrossRef] [PubMed]

145. Tyrväinen, L.; Ojala, A.; Korpela, K.; Lanki, T.; Tsunetsugu, Y.; Kagawa, T. The influence of urban green environments on stress relief measures: A field experiment. J. Environ. Psychol. 2014, 38, 1-9. [CrossRef] 
146. Gatersleben, B.; Andrews, M. When walking in nature is not restorative-The role of prospect and refuge. Heal. Place 2013, 20, 91-101. [CrossRef]

147. Lobovikov, M.; Ball, L.; Paudel, S.; Guardia, M.; Piazza, M.; Russo, L.; Wu, J.; Ren, H. World Bamboo Resources A Thematic Study Prepared in the Framework of the World Bamboo Resources A Thematic Study Prepared in the framEwork of the Global Forest Resources Assessment 2005; Food and Agriculture Organization: Rome, Italy, 2007.

148. Hassan, A.; Tao, J.; Li, G.; Jiang, M.; Aii, L.; Zhihui, J.; Zongfang, L.; Qibing, C. Effects of Walking in Bamboo Forest and City Environments on Brainwave Activity in Young Adults. Evid.-Based Complement. Altern. Med. 2018, 2018, 1-9. [CrossRef]

149. Barkmann, J.; Glenk, K.; Keil, A.; Leemhuis, C.; Dietrich, N.; Gerold, G.; Marggraf, R. Confronting unfamiliarity with ecosystem functions: The case for an ecosystem service approach to environmental valuation with stated preference methods. Ecol. Econ. 2008. [CrossRef]

150. Horiuchi, M.; Endo, J.; Takayama, N.; Murase, K.; Nishiyama, N.; Saito, H.; Fujiwara, A. Impact of viewing vs. Not viewing a real forest on physiological and psychological responses in the same setting. Int. J. Environ. Res. Public Health 2014, 11, 10883-10901. [CrossRef]

151. Song, C.; Ikei, H.; Miyazaki, Y. Physiological effects of visual stimulation with forest imagery. Int. J. Environ. Res. Public Health 2018, 15. [CrossRef]

152. Ikei, H.; Song, C.; Miyazaki, Y. Physiological effects of touching wood. Int. J. Environ. Res. Public Health 2017. [CrossRef]

153. Ikei, H.; Song, C.; Miyazaki, Y. Physiological effect of olfactory stimulation by Hinoki cypress (Chamaecyparis obtusa) leaf oil. J. Physiol. Anthropol. 2015, 34. [CrossRef]

154. Song, C.; Ikei, H.; Miyazaki, Y. Physiological effects of forest-related visual, olfactory, and combined stimuli on humans: An additive combined effect. Urban. For. Urban. Green. 2019, 44. [CrossRef]

155. Park, B.-J.; Morikawa, T.; Ogata, T.; Washida, K.; Iwamoto, M.; Nakamura, H.; Miyazaki, Y. Physiological Effects of Ingesting Eucalyptus Essential Oil with Milk Casein Peptide. Sliva Fenn 2009, 43, 173-179. [CrossRef]

156. Elsadek, M.; Sun, M.; Sugiyama, R.; Fujii, E. Cross-cultural comparison of physiological and psychological responses to different garden styles Cross-cultural comparison of physiological and psychological responses to different garden styles. Urban. For. Urban. Green. 2018, 38, 74-83. [CrossRef]

157. Song, C.; Ikei, H.; Lee, J.; Park, B.-J.; Kagawa, T.; Miyazaki, Y. Individual differences in the physiological effects of forest therapy based on Type A and Type B behavior patterns. J. Physiol. Anthropol. 2013, 32. [CrossRef] [PubMed]

158. Takayama, N.; Morikawa, T.; Bielinis, E. Relation between psychological restorativeness and lifestyle, quality of life, resilience, and stress-coping in forest settings. Int. J. Environ. Res. Public Health 2019, 16. [CrossRef] [PubMed]

159. Park, B.-J.B.J.; Furuya, K.; Kasetani, T.; Takayama, N.; Kagawa, T.; Miyazaki, Y. Psychological evaluations of forest environment and the physical variables. For. Med. 2013, 37-54.

160. Shin, W.S.; Shin, C.S.; Yeoun, P.S. The influence of forest therapy camp on depression in alcoholics. Environ. Health Prev. Med. 2012, 17, 73-76. [CrossRef] [PubMed]

161. Song, C.; Ikei, H.; Kobayashi, M.; Miura, T.; Taue, M.; Kagawa, T.; Li, Q.; Kumeda, S.; Imai, M.; Miyazaki, Y. Effect of forest walking on autonomic nervous system activity in middle-aged hypertensive individuals: A pilot study. Int. J. Environ. Res. Public Health 2015, 12, 2687-2699. [CrossRef]

162. Mao, G.; Cao, Y.; Wang, B.; Wang, S.; Chen, Z.; Wang, J.; Xing, W.; Ren, X.; Lv, X.; Dong, J.; et al. The Salutary Influence of Forest Bathing on Elderly Patients with Chronic Heart Failure. Int. J. Environ. Res. Public Health 2017. [CrossRef]

163. Savoia, C.; Schiffrin, E.L. Inflammation in hypertension. Curr. Opin. Nephrol. Hypertens. 2006, 15, $152-158$. [CrossRef]

164. Jia, B.B.; Yang, Z.X.; Mao, G.X.; Lyu, Y.D.; Wen, X.L.; Xu, W.H.; Lyu, X.L.; Cao, Y.B.; Wang, G.F. Health Effect of Forest Bathing Trip on Elderly Patients with Chronic Obstructive Pulmonary Disease. Biomed. Environ. Sci. 2016, 29, 212-218. [CrossRef] [PubMed]

165. Han, J.-W.; Choi, H.; Jeon, Y.-H.; Yoon, C.-H.; Woo, J.-M.; Kim, W. The effects of forest therapy on coping with chronic widespread pain: Physiological and psychological differences between participants in a forest therapy program and a control group. Int. J. Environ. Res. Public Health 2016, 13. [CrossRef] [PubMed] 
166. Yu, Y.-M.; Lee, Y.-J.; Kim, J.-Y.; Yoon, S.-B.; Shin, C.-S. Effects of forest therapy camp on quality of life and stress in postmenopausal women. Forest Sci. Technol. 2016, 12, 125-129. [CrossRef]

167. Markevych, I.; Schoierer, J.; Hartig, T.; Chudnovsky, A.; Hystad, P.; Dzhambov, A.M.; de Vries, S.; Triguero-Mas, M.; Brauer, M.; Nieuwenhuijsen, M.J.; et al. Exploring pathways linking greenspace to health: Theoretical and methodological guidance. Environ. Res. 2017, 158, 301-317. [CrossRef] [PubMed]

168. Pinder, R.; Kessel, A.; Green, J.; Grundy, C. Exploring perceptions of health and the environment: A qualitative study of Thames Chase Community Forest. Heal. Place 2009, 15, 349-356. [CrossRef] [PubMed]

(C) 2020 by the authors. Licensee MDPI, Basel, Switzerland. This article is an open access article distributed under the terms and conditions of the Creative Commons Attribution (CC BY) license (http://creativecommons.org/licenses/by/4.0/). 